\title{
Tropospheric mixing ratios of NO obtained during TROPOZ II in the latitude region $67^{\circ} \mathrm{N}-56^{\circ} \mathrm{S}$
}

\author{
Franz Rohrer, Dirk Brüning, and Dieter H. Ehhalt \\ Institut für Atmosphärische Chemie, Forschungszentrum Jülich, Germany
}

\begin{abstract}
Vertical profiles of NO were measured during the TROPOZ II aircraft campaign in January 1991. Altogether, 30 flights were made along the coastlines of western Europe, eastern North America, South America, and western Africa, covering latitudes between $67^{\circ} \mathrm{N}$ and $56^{\circ} \mathrm{S}$ and altitudes between 0 and $11 \mathrm{~km}$. As a result of the general wind pattern, westerly winds at all northern and southern midlatitudes, the NO data show large-scale outflow of NO-polluted air along the east coasts of the North and South American continents and inflow of clean maritime air over the west coasts of South America, North Africa, and Europe. The NO concentrations in the free tropospheric air flowing out from the (winter) North American continent lie between 100 and 300 parts per trillion by volume (pptv) with a weakly C-shaped vertical profile. The air coming off the (summer) South American continent has a factor of 3 lower NO concentrations, between 40 and 100 pptv, but a more pronounced C-shaped vertical profile with NO mixing ratios of up to 200 pptv in the upper troposphere of the tropics. The salient features in the NO distribution are discussed with the help of 3 day back trajectories.
\end{abstract}

\section{Introduction}

The nitrogen oxides $\mathrm{NO}$ and $\mathrm{NO}_{2}$ play a key role in the photochemistry of the troposphere. They influence the concentration of the $\mathrm{OH}$ radical, which determines the atmospheric lifetimes of many trace species. At the same time, the $\mathrm{NO}_{x}$ species control the photochemical production of ozone in the troposphere. Both functions are interrelated and depend on the concentration of nitrogen oxides in a strongly nonlinear way.

To characterize the current photochemical state of the troposphere and its possible change due to anthropogenic emissions, it is very important to establish the distribution of $\mathrm{NO}_{x}$ in the troposphere. This is not an easy task. Because of its short lifetime and the large variety of sources [see Ehhalt et al., 1992] the tropospheric mixing ratios of $\mathrm{NO}_{x}$ are highly variable. Thus it will take a large number of measurements to establish a climatology of its tropospheric distribution. The NO measurements presented in this paper are another step in this direction. They were obtained during the TROPOZ II aircraft campaign in January 1991. The flight track of the TROPOZ II campaign is shown in Figure 1. It is virtually the same as that of the STRATOZ III campaign which took place in June 1984. The NO sampling density of TROPOZ II (see Figure 2) is also comparable to that of the earlier cam-

Copyright 1997 by the American Geophysical Union.

Paper number $97 \mathrm{JD} 01853$.

0148-0227/97/97JD-01853\$09.00 paign [Drummond et al., 1988]. Thus it may eventually be possible to investigate the $\mathrm{NO}_{x}$ results from both campaigns for seasonal differences.

Both expeditions were carried out on board the Caravelle 116 aircraft of the Centre d'Essais en vol, Brétigny, France. The measurements cover the latitude range $67^{\circ} \mathrm{N}$ to $56^{\circ} \mathrm{S}$ and altitudes of $0-11 \mathrm{~km}$. A number of other measurements were made and are partly published: peroxyacetyl nitrate [Perros, 1994] and $\mathrm{H}_{2} \mathrm{O}_{2}$; formaldehyde and acetaldehyde [Arlander et al., 1995a,b]; formaldehyde, $\mathrm{CO}, \mathrm{H}_{2} \mathrm{O}_{2}$, and $\mathrm{NO}_{2}$ [Roths, 1992; Roths and Harris, 1996]; $\mathrm{SO}_{2}$ [Wolz, 1992]; temperature, wind and pressure, which were recorded by the aircraft navigation system (A. Marenco, unpublished manuscript, 1996); ozone, methane, and carbon monxide [Gouget et al., 1996; A. Marenco, unpublished manuscript, 1996]; $\mathrm{NO}_{2}$ photolysis frequency and $\mathrm{NO}_{y}$ mixing ratio (F. Rohrer, unpublished manuscript, 1996). In this paper we concentrate on the presentation of the NO data measured during TROPOZ II, in particular on the vertical profiles, which were obtained during the ascent from and descent to the various airports. As Figure 2 indicates, there were 60 profiles altogether. However, we will also present plots of the latitude by altitude contours of the NO mixing ratio to emphasize the organization of the individual NO profiles into largescale patterns.

\section{Instrumentation}

The instrument used during the TROPOZ II campaign was essentially the same as that used during 
$500 \mathrm{hPa}$

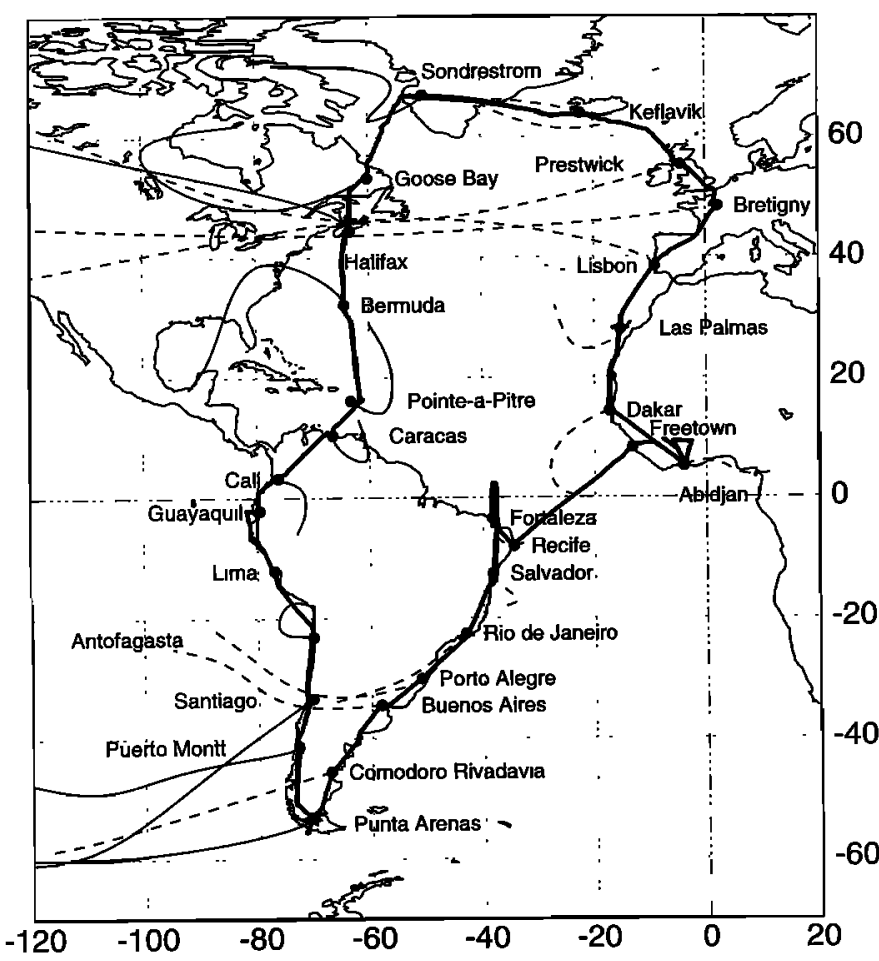

Figure 1. Flight track of the TROPOZ II expedition, January 1991. The thin lines indicate the 3 day back trajectories (ECMWF) calculated for $500 \mathrm{hPa}$ during the ascents of the aircraft at the different airports. (Solid lines refer to the southbound and dashed lines to the northbound flight sections.)

STRATOZ III. A complete description of its original design, refinements, and operation is given by Drummond et al. [1985, 1988] and Rohrer and Brüning [1992]. It is based on earlier developments of Ridley and Howlett [1974] and Kley and McFarland [1980]. Here we give a brief description of the instrument used and the actual operational parameters.

The detection system is based on the chemiluminescent reaction of ambient NO with added ozone. The fluorescence of $\mathrm{NO}_{2}$ formed in this reaction is detected through a filter (RG610) by a photomultiplier (EMI 9658R, operated at $1.8 \mathrm{kV}$ ). The signal of the photomultipliertubes (PMT) is amplified by an amplifier/discriminator system (EMI C604) and accumulated by an 8086 computer system equipped with 32-bit counters.

The instrument consists of four chemiluminescence NO detectors operated in parallel. Three channels are used to measure ambient $\mathrm{NO}, \mathrm{NO}_{y}$, and $\mathrm{NO}_{2}$. The fourth channel is used to check for possible sensitivity changes by adding a constant and known amount of NO to the ambient airflow of that detector. This detector signal is called NOcal. All NO detectors share several support systems: the dry ice cooled PMT housing, the ozone generator, the pump (Alcatel model 2012A), the ozone destroyer, the electronics, the computer system, the calibration system, and the first part of the inlet tube.

The concentration of the added ozone is nonitored by a dual-beam photometer. Its signal is used for the stabilization of the ozone concentration. The ozone $/ \mathrm{O}_{2}$ mixture was purified by flowing it through a water bubbler operated at $37^{\circ} \mathrm{C}$. The use of this water bubbler reduces the background current of the detection system at ground level from 1000 counts per second (cps) to $200 \mathrm{cps}$ and additionally humidifies the airflow through the reaction vessels [see Drummond et al., 1985].

The background signal including the fluorescence of some of the interfering chemiluminescence reactions is determined in the zero mode of the detector by using a relaxation volume. The residence times and the addition of ozone are adjusted so that $90 \%$ of the $\mathrm{NO}_{2}$ fluorescence takes place in the relaxation volume. The background current of the photomultiplier system measured under ambient conditions with small amounts of NO depends on altitude. At sea level the background signal was around $200 \mathrm{cps}$, increasing by a factor of 4 at altitudes around $11 \mathrm{~km}$. The sensitivity of the NO detector as determined during calibrations is around 1.5 cps per part per trillion by volume (pptv) of NO with $1 \mathrm{~L} / \mathrm{min}$ STP of ambient air.

The inlet system consists of a $6 \mathrm{~mm}$ Teflon (polytetrafluorethylene PTFE) tube inside a stainless steel tube. The Teflon tube is exactly aligned with the stainless steel tube, not extending beyond its end to avoid production of NO by corona discharge. It is located on top of the fuselage approximately $12 \mathrm{~m}$ behind the nose and $20 \mathrm{~cm}$ above the surface and is pointed rearward. The depth of the aircraft boundary layer at that point is estimated to 6 and $10 \mathrm{~cm}$ [Drummond et al., 1988]. The total length of the inlet tube is $1.75 \mathrm{~m}$. In front of each detector a small ceramic body with a pinhole is placed in the inlet tube. The differential pressure measured at this pinhole controls a motor-driven Teflon needle valve. This mass flow controller system is able to stabilize the inlet flow of each detector system to approximately $2 \%$ even at fast descents. The inlet tube is backflushed near the airports with a flow of $5 \mathrm{~L} / \mathrm{min}$ STP synthetic air to prevent contamination of the inner surface. After the ground calibration procedure the Teflon needle valves are closed, and the inlet tube is completely drawn inside the cabin and sealed by a Teflon stopper.

The photon pulses of the detection system are integrated over $5 \mathrm{~s}$ intervals and stored by the computer. After six integration periods the detection system switches from measure mode to zero mode and vice versa. The first integration period after each mode change is disregarded to suppress the influence of possible artifacts during the time of valve operation. The mean of five measurement periods is corrected by the mean of the neighboring zero modes and multiplied by the sensitivity of the detector. No correction for the quenching of the $\mathrm{NO}_{2}$ fluorescence by ambient water in 

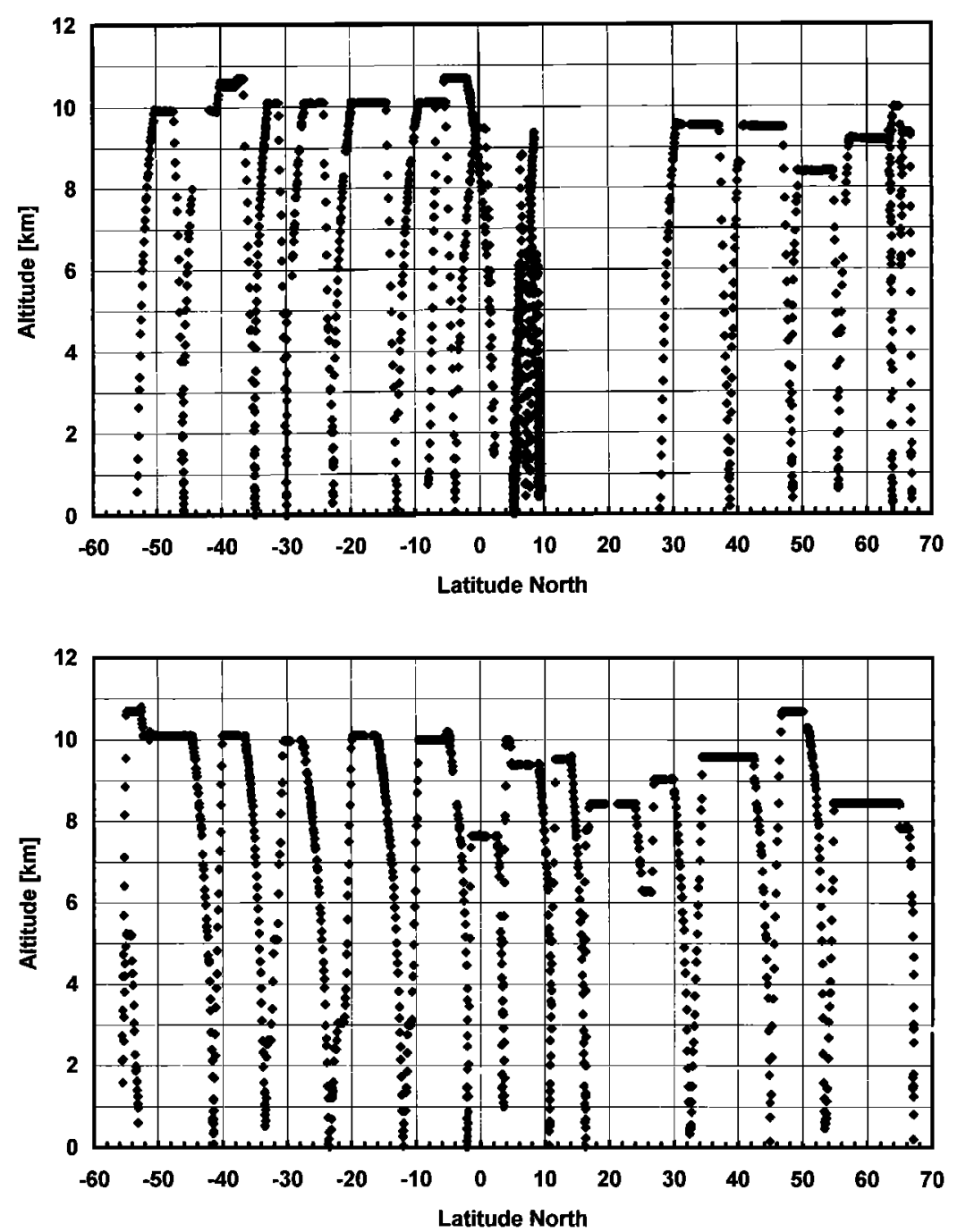

Figure 2. Latitude-altitude position of the NO measurements for the (top) northbound and (bottom) southbound flights.

the reaction vessel or for the reaction of NO with ambient ozone inside the inlet tube is applied. Because of the low water concentration in the free troposphere and the short residence time (0.4-0.1 s) of the air sample inside the inlet line a maximum correction of $1 \%$ above $1 \mathrm{~km}$ altitude is calculated. This is included in the estimation of the overall systematic error.

\section{Calibration}

Calibrations on the ground and in flight are performed by adding a known concentration of NO in synthetic air. To this end a calibrated flow of NO (approximately $10 \mathrm{~mL} / \mathrm{min} \mathrm{STP} 2 \mathrm{ppm} \mathrm{NO}$ in $\mathrm{N}_{2}$, AIRCO/BOC Spectra Seal) is diluted by synthetic air $(5 \mathrm{~L} / \mathrm{min} \mathrm{STP}$, Linde) and fed into the inlet tube (approximately $35 \mathrm{~cm}$ behind the inlet) before and after each flight and during some of the flights at cruising altitude. Because of this setup the first $35 \mathrm{~cm}$ of the inlet tube were not tested during the calibration pro- cedure. The thermal mass flow controllers (MKS) for $\mathrm{NO} / \mathrm{N}_{2}$ and synthetic air are calibrated several times during the campaign by soap bubble flowmeters. The Spectra Seal cylinder used during the campaign is compared with others in the laboratory before and after the campaign, showing differences of less than $2 \%$. In addition to the calibration by the manufacturer, the used $\mathrm{NO} / \mathrm{N}_{2}$ mixture is calibrated in the laboratory by gas phase titration of NO with $\mathrm{O}_{3}$ and subsequent analysis of the excess $\mathrm{O}_{3}$ by a UV photometer (Antechnica $\mathrm{O}_{3}-41 \mathrm{M}$ ). During flights the $\mathrm{NO} / \mathrm{N}_{2}$ mixture is added to the sample airflow analyzed by the NOcal detector. After subtraction of the signal of the NO detector this NOcal signal is used to check for possible sensitivity changes of the NOcal channel during the flights. Sensitivity changes might originate from changes of pressure or temperature inside the aircraft, from fluctuations of the aircraft power supply during the flights, or from changes of external conditions such as passage through clouds. The effect of these possible error sources should 
Table 1. Sensitivity of the NOcal and NO Detectors During Flight 14D

\begin{tabular}{ccccc}
\hline Time, UT & Altitude, $\mathbf{k m}$ & $\mathrm{S}_{\text {NOcal }}, \mathrm{cps} / \mathrm{pptv}$ & $\mathrm{S}_{\text {NO }}, \mathrm{cps} / \mathrm{pptv}$ & Note \\
\hline 1405 & 10.1 & 1.245 & 1.592 & in-flight calibration \\
1437 & 9.4 & 1.272 & & \\
1441 & 7.3 & 1.240 & & \\
1445 & 5.4 & 1.233 & & \\
1449 & 3.4 & 1.254 & & \\
1453 & 1.2 & 1.261 & & \\
1457 & 0.7 & 1.231 & 1.598 & ground calibration \\
1511 & 0.0 & 1.252 & & \\
\hline
\end{tabular}

Flight $14 \mathrm{D}$ is the descent to Puerto Montt. Sensitivity (in counts per second per pptv NO) was measured at a signal level of $4 \mathrm{ppbv}$ NO.

be comparable for all NO channels used during the flights. Table 1 gives an example of changes in sensitivity of the NOcal detector during the descent to Puerto Montt. These in situ measurements of instrument sensitivity are accompanied by the appropriate in-flight calibration and calibration at ground for the NOcal and NO detectors.

The NOcal measurements give no hint of a significant change of the sensitivity of the NOcal detector during in-flight operation. The calibration procedure results in an estimated overall systematic error of less than $15 \%$. This error estimate includes contributions from the preparation of the calibration flow by mass flow controllers $(2 \%$, estimated from observed differences between the in-flight calibrations and calibrations at ground), from the maximum correction for the quenching of $\mathrm{NO}_{2}$ by ambient water and the reaction of NO with ozone inside the inlet tube (1\%), and from the comparison of the calibration gas cylinder with others in the laboratory before and after the campaign (2\%). But the major error contribution results from the un-

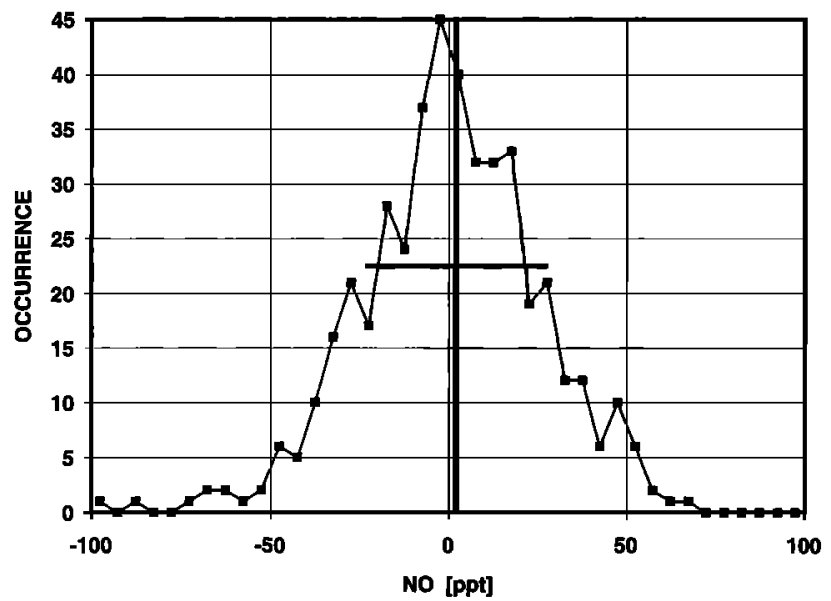

Figure 3. Frequency distribution of the NO mixing ratio during the nighttime measurements (zenith angle greater than $100^{\circ}$ ) of flights 3,6 , and 22 . The heavy horizontal bar indicates the mean standard deviation : \pm 25 pptv. certainty of the absolute concentration of NO in the $\mathrm{NO} / \mathrm{N}_{2}$ calibration mixture, which is estimated to be of the order of $10 \%$.

Synthetic air out of aluminum cylinders is used before and after each calibration and during flights to check the zero point of the instruments. At the beginning of the campaign until Bermuda a small positive offset of 2-5 pptv NO is measured and subtracted from the ambient air measurements. During the other flights the offset is less than $2 \mathrm{pptv}$, and no correction is applied to the ambient air measurements. As a measure of possible artifacts the ambient air signal of the NO detector during solar zenith angles higher than $100^{\circ}$ (flights 3 , 6 , and 21) is used to calculate the frequency distribution of this signal, as shown in Figure 3. This distribution gives a mean and standard deviation of $2 \pm 25$ pptv NO for $25 \mathrm{~s}$ integration time. Based on this frequency distribution, the detection limit is $50 \mathrm{pptv}$, corresponding to $2 \sigma$. At some locations (for example, flight 3) the variation around zero appears strongly dependent on altitude, possibly indicating the influence of cosmic rays. The variation of the signal during flights and during ground operation is approximately 3 and 1.5 times higher, respectively, than that expected by photon counting statistics. The changes in the design of the instrument used in the STRATOZ III expedition were intended mainly to improve the reliability and handling of the system. Detection limit and sensitivity of the instrument were comparable for both the STRATOZ III and TROPOZ II campaigns.

\section{Results}

An example of a NO data record is shown in Figure 4 along with some auxiliary information measured in flight and pertinent to the NO measurement, namely, altitude, ozone mixing ratio (UV photometer, A. Marenco, unpublished manuscript, 1996), and the photolysis frequency of $\mathrm{NO}_{2}, \mathrm{~J}\left(\mathrm{NO}_{2}\right)$ (two filter radiometers, Junkermann et al., 1989). The data are from flight 20 , which went from Rio de Janeiro, $18^{\circ} \mathrm{S}$, to Salvador, $13^{\circ} \mathrm{S}$ latitude, on January 25,1991 . The NO 

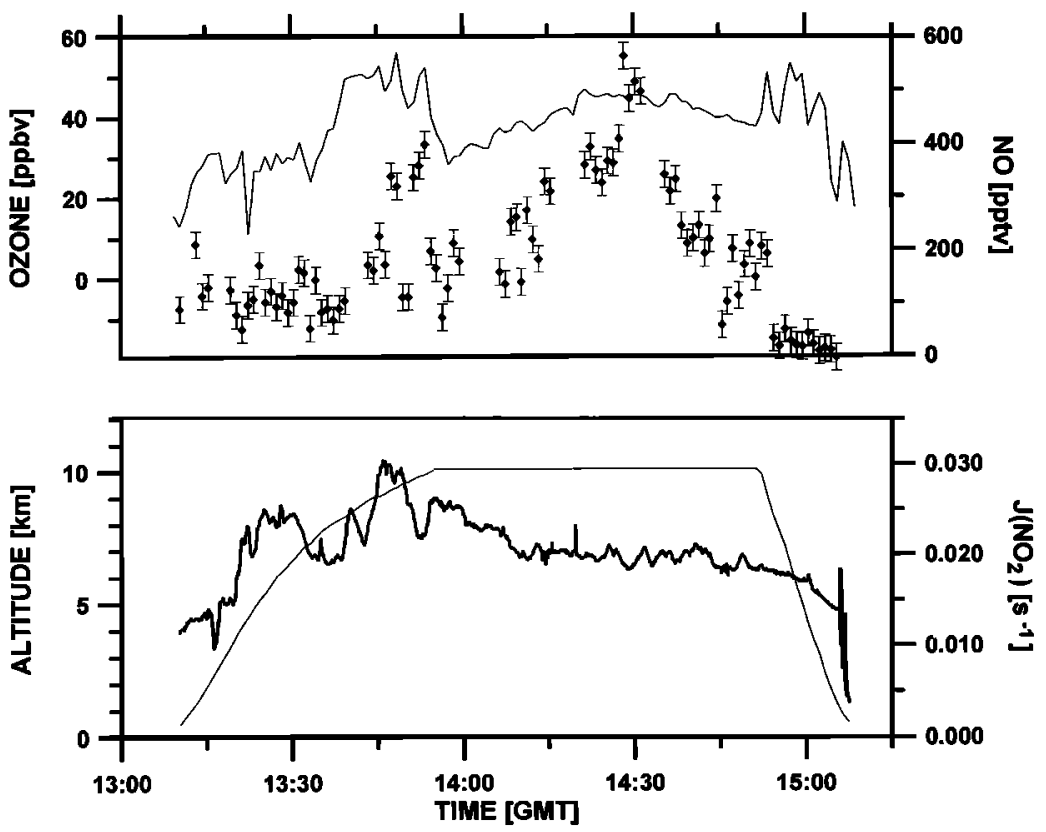

Figure 4. (top) Time series of the $25 \mathrm{~s}$ averages of the NO mixing ratio (diamonds) during flight 20, Rio de Janeiro-Salvador, 25.1.1991, $23^{\circ} \mathrm{S}-13^{\circ} \mathrm{S}, 43^{\circ} \mathrm{W}-38^{\circ} \mathrm{W}$, solar zenith angle $25^{\circ}-5^{\circ}$. The error bars denote the mean standard deviation of NO as derived from Figure 3. Also shown are (bottom) flight altitude (thin line), photolysis frequency of $\mathrm{NO}_{2}$ (thick line) and (top) ozone (thin line), all measured on board the aircraft.

data exhibit an extended and strong maximum around $1430 \mathrm{UT}$ at the cruising altitude of $10 \mathrm{~km}$. An analysis of the back trajectory (see also below) indicates that that air originated 3 days earlier at an altitude of 820 $\mathrm{hPa}$ over the central South American continent $\left(20^{\circ} \mathrm{S}\right.$, $60^{\circ} \mathrm{W}$ ). Thus Figure 4 provides an interesting example of the effect of fast vertical transport of polluted air from the planetary boundary layer on the trace gas levels in the upper troposphere.

Generally, however, the major systematic changes in such a NO record are associated with the large changes in altitude during the ascent to or the descent from the cruising altitude to the surface. That is, they occur during the first and last $30 \mathrm{~min}$ of a flight.

Thus in the following, we will primarily extract the vertical NO distributions from the data, as the most immediately available and most important information. The resulting vertical profiles are shown in Figures 5-18. The flights are numbered and appear in the sequence in which they were carried out, with a separate panel for the ascending (A) and descending (D) branch of each flight. The panels present the NO data collected during ascent or descent including only the first and last two data points at cruising altitude, respectively. We also note that during the $25 \mathrm{~s}$ required for the ambient NO measurement the aircraft moved several $100 \mathrm{~m}$ vertically and several kilometers horizontally. Thus each data point presents an average over a substantial spatial scale.

Not all flights permitted NO measurements. For example, because of weight limitations during the transfer flight from South America to Africa (flights 23 and 24 from Recife to Freetown to Abidjan), most scientists had to leave the Caravelle and travel by commercial aircraft.

The section of the flight track covered during ascent or descent can easily be reconstructed by transposing the latitude range given in each panel onto Figure 1. Since the aircraft often covered horizontal distances of several hundreds of kilometers while descending from or climbing to the cruising altitude (cf. Figures 2 and 4), the term "vertical profile" is somewhat of a figure of speech. It is important to note here that in most cases decreasing altitude means at the same time decreasing distance to the airports. For this reason the reader must be cautious when looking at the vertical profiles. The measurements at lower altitude (normally below 1 $\mathrm{km}$ ) might not reflect "background" conditions. In most cases they are probably influenced by the more populated regions near the airports. Each flight will be commented on briefly with respect to wind and cloud conditions or other significant meteorological features. In particular, we describe the essential features of the isentropic back trajectories calculated by G. Wolz [Wolz, 1992], using wind fields from the European Center for Medium Range Weather Forecasting (ECMWF). The trajectories were calculated for 1200 and 1800 UT of the actual days and locations of the aircraft, each extending back 3 days. They have uncertainties associated with data sparse regions, especially in the southern hemisphere, and can give only a hint to the "real" origin of air masses. In order to also present the essence of the 

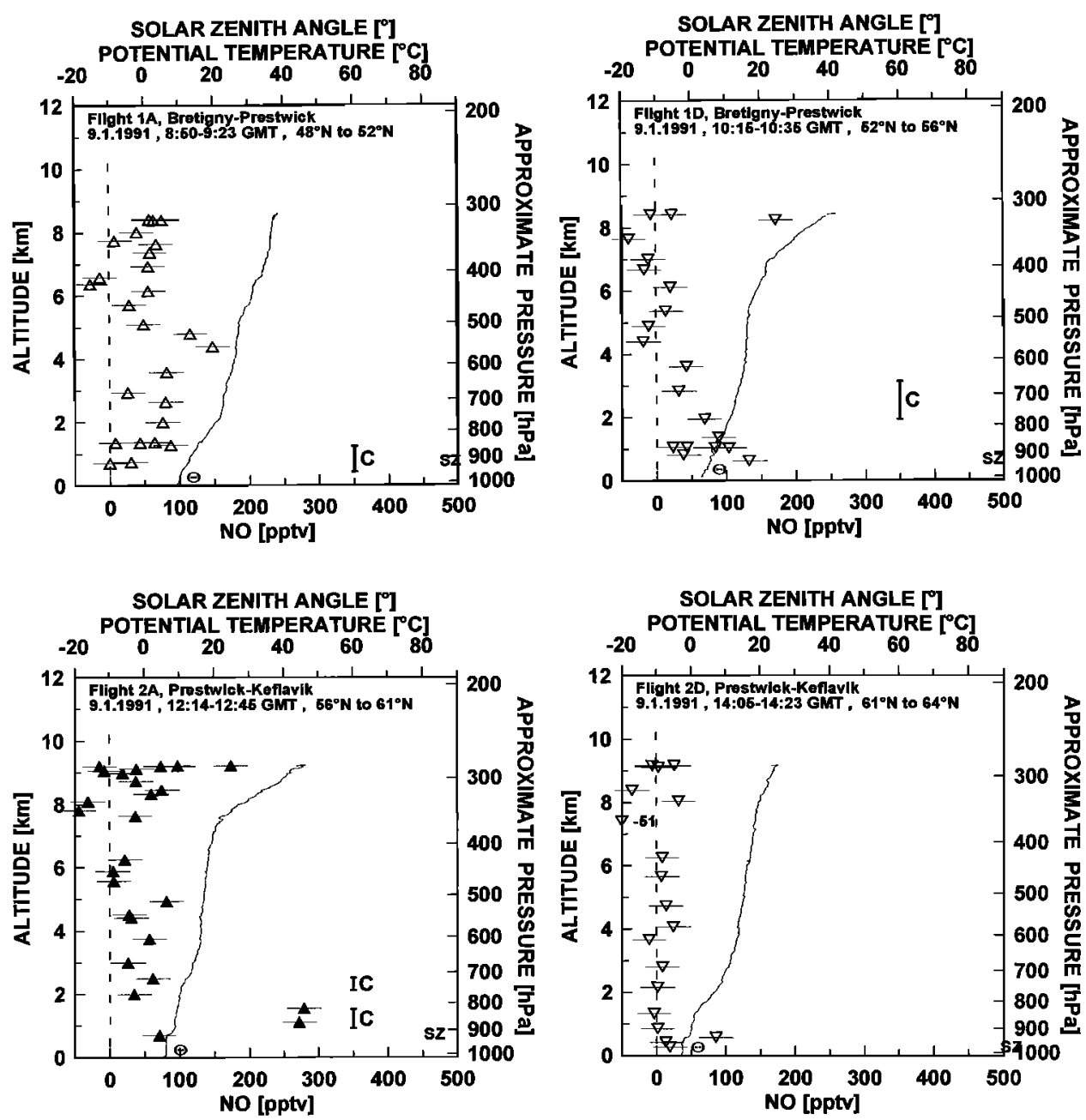

Figure 5. Vertical profiles of the NO mixing ratio (top) during flight 1, Brétigny-Prestwick, and (bottom) during flight 2, Prestwick-Keflavik. Solid triangles represent $25 \mathrm{~s}$ averages of the NO measurements during daytime (zenith angle $<80^{\circ}$ ). They are separated by a $35 \mathrm{~s}$ time interval required for the mode switching and the zero mode of the instrument. Open triangles represent measurements taken at solar zenith angles greater than $80^{\circ}$. The altitude of the data points represents the altitude of the aircraft at the center of each $25 \mathrm{~s}$ integration period. The error bars denote the mean standard deviation of NO as derived from Figure 3. NO data falling outside the plot are indicated at the boundary of the plot with their associated mixing ratio. Also given are the potential temperature $\Theta$ and the solar zenith angle SZ. Solid vertical lines mark the position of clouds (C) or haze (H), recorded by a video system on board the aircraft.

data collected at cruising altitude, all of the NO data are summarized in the form of latitude by altitude cross sections in Figures 19 and 20.

During the early part of the campaign, i.e., in winter at high northern latitudes, solar zenith angles were near $90^{\circ}$. As a consequence the partitioning between $\mathrm{NO}$ and $\mathrm{NO}_{2}$ is largely or completely shifted in favor of $\mathrm{NO}_{2}$, and the NO data are not directly comparable to those made in bright sunlight. High solar zenith angles were also encountered during some of the later flights. They are emphasized by the use of open symbols for the NO data whenever the solar zenith angle exceeded $80^{\circ}$. In addition, the local solar zenith angle is also given in Figures 5 to 18. Eventually, when the simultane- ous data on $\mathrm{O}_{3}$ and $\mathrm{J}\left(\mathrm{NO}_{2}\right)$ become available, many of these NO data can be converted to the better conserved mixing ratio of $\mathrm{NO}_{x}=\mathrm{NO}+\mathrm{NO}_{2}$. Those made in complete darkness, when NO concentrations are zero, serve as a useful test for bias and precision of the in-flight NO measurement (see Figure 3).

\section{Flight 1}

The campaign began on January 9, 1991, at 0850 UT with the ascent of flight 1 from the Centre d'Essais en Vol, Brétigny, $48^{\circ} \mathrm{N}$ latitude, near Paris, France. Clouds were present during the lowest $1 \mathrm{~km}$ of the ascent. Winds were from west to southwest during the whole flight. The back trajectories originated over 

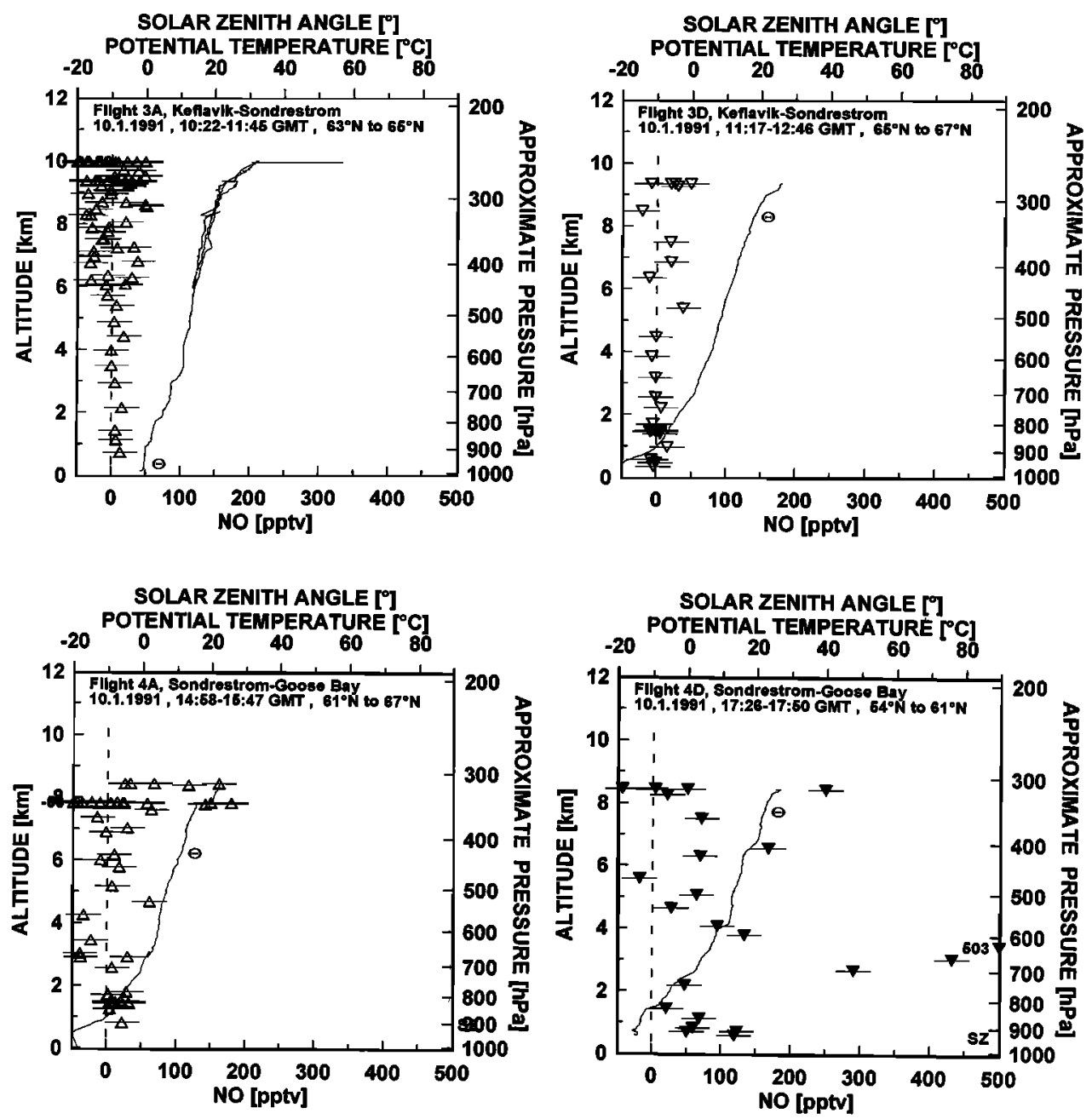

Figure 6. Vertical profiles of the NO mixing ratio (top) during flight 3, Keflavik-Sondrestrom, and (bottom) during flight 4, Sondrestrom-Goose Bay. See Figure 5 for explanation of the symbols.

North America at all altitudes above $700 \mathrm{hPa}$ and indicated a crossing time of the Atlantic of about 2 days. During ascent the aircraft did not reach the tropopause. But it moved into stratospheric air while cruising at 8.6 $\mathrm{km}$ altitude and crossed the tropopause during the descent at $7 \mathrm{~km}$ altitude as indicated by the potential temperature in Figure 5a. During the further descent to Prestwick, clouds were encountered between 5 and 2 $\mathrm{km}$ altitude accompanied by snow and rain.

\section{Flight 2}

Flight 2 followed on the same day, January 9, 1991. Up to $2 \mathrm{~km}$ the aircraft flew through two cloud levels, the lower one accompanied by high NO mixing ratios of nearly 300 pptv. Winds were still from west-southwest, and the back trajectories indicate air masses originating from the North American continent. During the climb from Prestwick the aircraft crossed the tropopause at $7.5 \mathrm{~km}$ altitude (see potential temperature in Figure $5 \mathrm{~b}$ ). During the cruise at maximum altitude (data are not shown in Figure 5b) the aircraft moved out of the stratosphere and was completely within the troposphere during the descent to Keflavik. Winds during descent were weak and for the most part from the west. The back trajectories show a complicated pattern and depended strongly on altitude. At $300 \mathrm{hPa}$ the 3 day back trajectories originate over Canada, at $500 \mathrm{hPa}$ the origin is immediately south of Iceland and at $950 \mathrm{hPa}$ the air came from Finland.

\section{Flight 3}

Flight 3, starting on January 10, 1991, at 1022 UT, at Keflavik, was conducted at solar zenith angles greater than $90^{\circ}$. The measured NO values were around zero at all altitudes, even at the airport. The scatter of the data seems to increase with altitude, especially over 6 km. Ascent and descent were within the troposphere.

\section{Flight 4}

Flight 4 continued on January 10, 1991, at 1458 UT, from Sondrestrom with high solar zenith angles around $90^{\circ}$. As a consequence the measured NO data were 

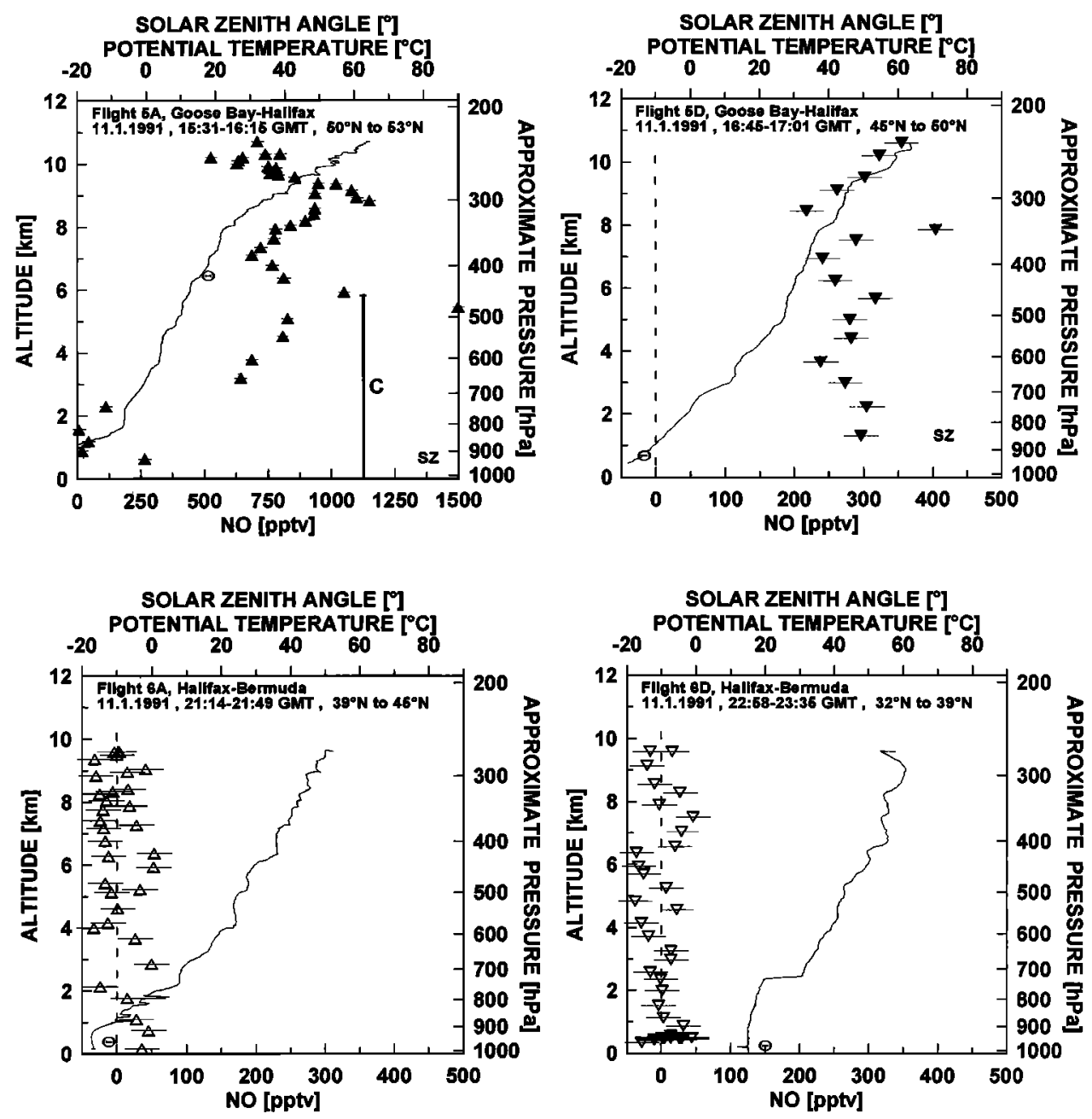

Figure 7. Vertical profiles of the NO mixing ratio (top) during flight 5, Goose Bay-Halifax, and (bottom) during flight 6, Halifax-Bermuda. See Figure 5 for explanation of the symbols.

around zero, except at altitudes higher than $8 \mathrm{~km}$ during the transfer flight to Goose Bay at solar zenith angles between $83^{\circ}$ and $86^{\circ}$. The vertical profile of NO at the descent to Goose Bay showed a highly layered structure with maxima at $6.5 \mathrm{~km}$ and $3.5 \mathrm{~km}$ altitude of $150 \mathrm{pptv}$ and $500 \mathrm{pptv}$, respectively. Both peaks were accompanied by steps in the vertical profile of potential temperature. The wind direction measured during the descent of the aircraft was southwest but shifted to north-northwest below $2.5 \mathrm{~km}$ altitude, where the NO values changed to low values around $50 \mathrm{pptv}$. All trajectories went back to the Great Lakes; those at the higher altitudes originated near the west coast of the United States.

\section{Flight 5}

On the following day, January 11, 1991, at 1531 UT, the ascent at Goose Bay took place through heavy clouds up to $6 \mathrm{~km}$ altitude. Local winds were from the west to northwest. The 3 day back trajectories were different from those of the day before. They had their origin over the Labrador Sea and reached the flight track on a strongly cyclonically curved path up to $500 \mathrm{hPa}$. The measured NO profile showed similar structure but much higher mixing ratios than that of the flight before: low values up to $2.5 \mathrm{~km}$ altitude, approximately $600 \mathrm{pptv}$ at $3.5 \mathrm{~km}$ altitude, but up to $1.5 \mathrm{ppbv}$ of NO at the top of the clouds, going back to $600 \mathrm{pptv}$ at $7 \mathrm{~km}$ altitude. These values were the highest values measured in the free troposphere during the whole campaign. The tropopause was located at $8 \mathrm{~km}$ altitude. Above, the NO values increased to a peak of $1 \mathrm{ppbv}$ at $9 \mathrm{~km}$ before they dropped to about $600 \mathrm{pptv}$ at $10 \mathrm{~km}$ altitude. During the descent to Halifax the flight track crossed the polar jet, which extended down to $6 \mathrm{~km}$ altitude with wind speeds over $60 \mathrm{~ms}^{-1}$. The NO vertical profile showed high values around $300 \mathrm{pptv}$ at all altitudes with an occasional variation up to $400 \mathrm{pptv}$ at $8 \mathrm{~km}$ altitude.

\section{Flight 6}

Flight 6 from Halifax to Bermuda took place during night. The measured NO values were around zero at all altitudes. 

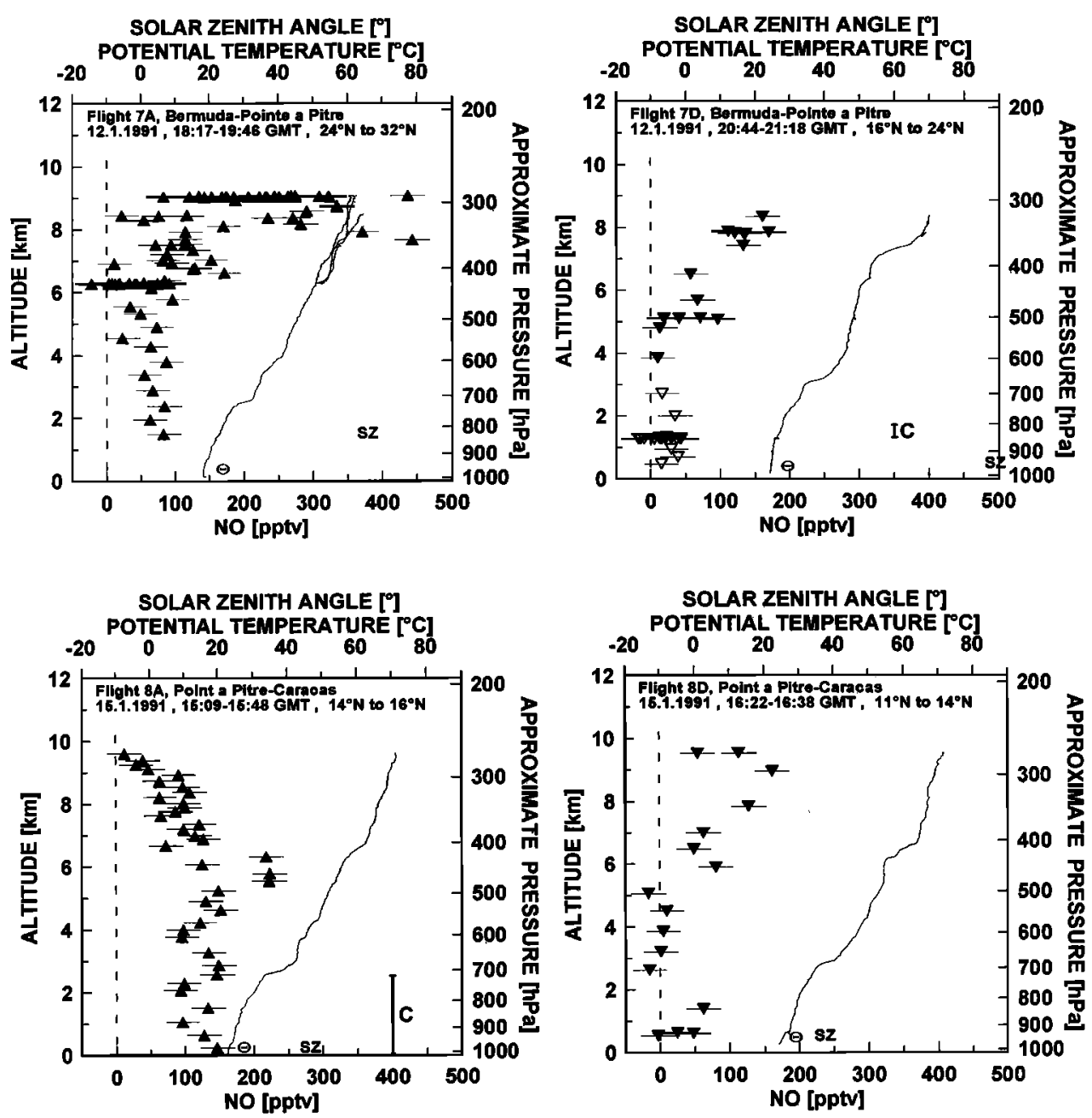

Figure 8. Vertical profiles of the NO mixing ratio (top) during flight 7, Bermuda-Pointe à Pitre, and (bottom) during flight 8, Pointe à Pitre-Caracas. See Figure 5 for explanation of the symbols.

\section{Flight 7}

The next day, January 12,1991 , at 1817 UT, the ascent from Bermuda showed an inversion layer at $3 \mathrm{~km}$ altitude, which was not expressed in the NO profile. The NO mixing ratios remained around $70 \mathrm{pptv}$ up to $6 \mathrm{~km}$ altitude. Above that altitude they increased, with two apparently enhanced values of about $400 \mathrm{pptv}$. The descent to Pointe à Pitre also showed higher values at altitudes above $5.5 \mathrm{~km}$ with a distinct stepwise decrease to zero NO levels below that altitude. This was correlated with a simultaneous change in wind direction from north to east. Scattered clouds were observed at $1.5 \mathrm{~km}$ altitude.

\section{Flight 8}

Three days later, January 15,1991 , at 1509 UT, the campaign continued with the ascent at Pointe à Pitre. Up to altitudes of $2.5 \mathrm{~km}$ the aircraft moved through clouds. Local winds were weak and from the east. The calculated back trajectories showed an origin of these air masses over the Atlantic. For oceanic air the NO values were relatively high at all altitudes, around 100 pptv. The sources of these relatively high NO mixing ratios measured are unknown. The descent at Caracas showed the same structure in potential temperature: two steps at $6 \mathrm{~km}$ and at $2.5 \mathrm{~km}$ altitude. But it showed a completely different NO profile, decreasing from around 150 pptv at $9 \mathrm{~km}$ to zero at lower altitudes. These relatively high NO mixing ratios could not be explained by the back trajectories. Within 3 days they encountered only maritime air masses. For $300 \mathrm{hPa}$ the 3 day back trajectories started near Cuba. At the lower altitudes below $500 \mathrm{hPa}$ the trajectories originated over the Atlantic east of Caracas, sometimes following the coastline.

\section{Flight 9}

The ascent from Caracas a few hours later on January 15,1991 , at $1831 \mathrm{UT}$, showed quite different NO values around 50 to $100 \mathrm{pptv}$ at all altitudes with two small peaks of $150 \mathrm{pptv}$ at $1.5 \mathrm{~km}$ and at $6 \mathrm{~km}$ altitude. During the descent to Cali, scattered clouds were encountered at $6 \mathrm{~km}$ altitude with lower NO values be- 

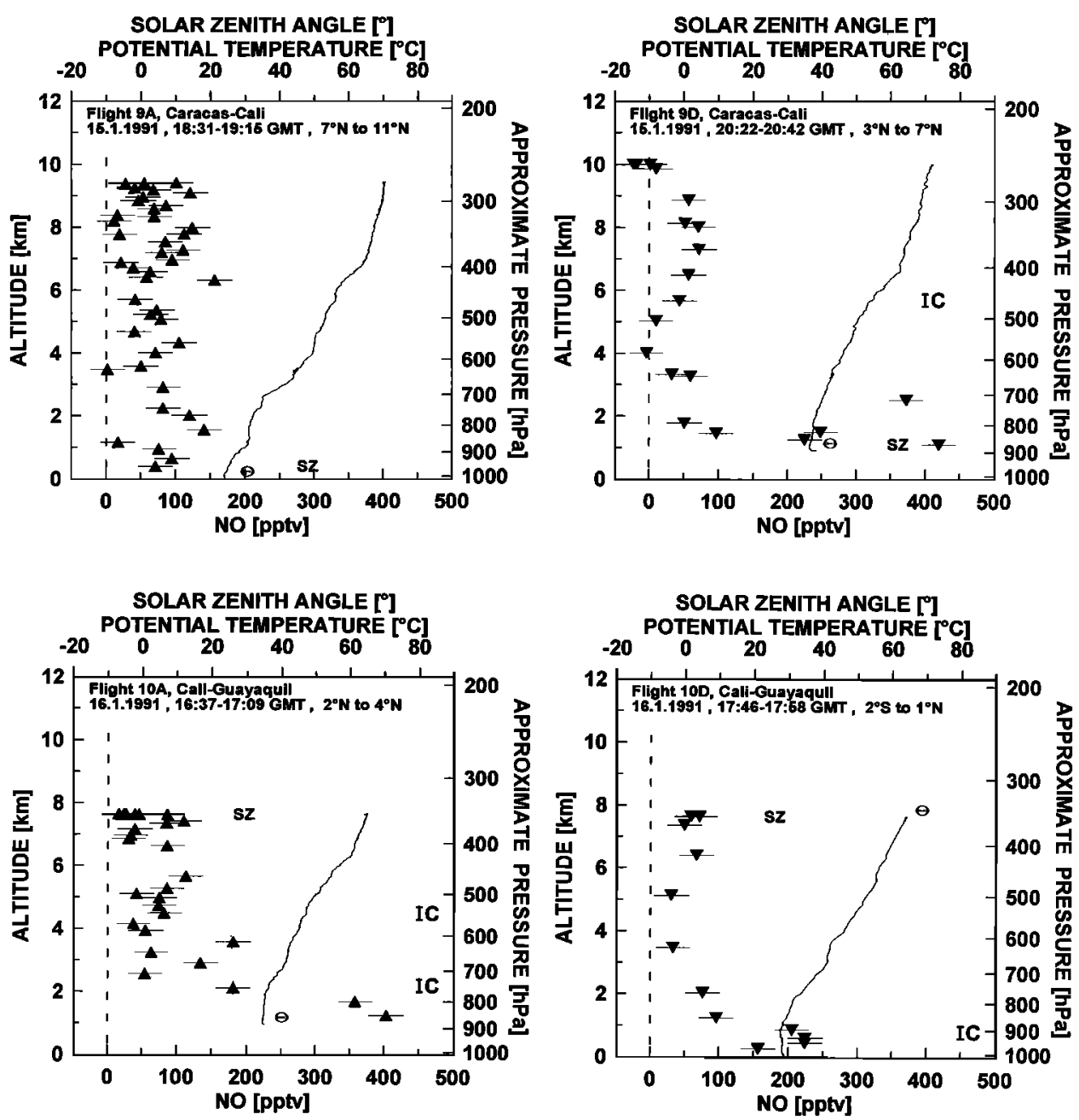

Figure 9. Vertical profiles of the NO mixing ratio (top) during flight 9, Caracas-Cali, and (bottom) during flight 10, Cali-Guayaquil. See Figure 5 for explanation of the symbols.

low the clouds. Cali is situated at $1 \mathrm{~km}$ above sea level inside a valley surrounded by high mountains. During the final descent the measurement below $3 \mathrm{~km}$ altitude showed some peaks reaching 400 pptv, possibly due to polluted air trapped in the valley.

\section{Flight 10}

The next day, January 16,1991 , at $1637 \mathrm{UT}$, during the ascent from Cali, high values up to $400 \mathrm{pptv}$ of NO in the altitude range 1 to $4 \mathrm{~km}$ were found, possibly showing the influence of the valley. At $2.5 \mathrm{~km}$ and $5 \mathrm{~km}$ altitude the aircraft was flying inside clouds. The back trajectories show that this air mass originated along the coast or offshore ocean and was lifted from the surface to 780 and to $700 \mathrm{hPa}$. The calculated trajectories above $500 \mathrm{hPa}$ had their origin over the Amazon basin. The measured NO values were around 50 to $100 \mathrm{pptv}$ for these altitudes. The descent to Guayaquil showed a Cshaped profile with $75 \mathrm{pptv}$ of NO at $8 \mathrm{~km}$ altitude, $25 \mathrm{pptv}$ in the middle troposphere, and $100 \mathrm{pptv}$ NO near the planetary boundary layer (PBL). Inside the
PBL, which seemed to be well mixed, the NO levels were around $200 \mathrm{pptv}$ with a sharp gradient at the top of the PBL at $1 \mathrm{~km}$ altitude. Once inside the PBL, the aircraft was flying through clouds. Winds were weak and from the south. The back trajectories indicate an origin of the air masses along the local shoreline.

\section{Flight 11}

The ascent from Guayaquil showed high values of NO (up to 600 pptv) inside the PBL with a sharp gradient across the top of the PBL at $1.5 \mathrm{~km}$ altitude. At this level the aircraft was flying through clouds again. For the rest of the ascent the NO mixing ratio varied between 50 and $100 \mathrm{pptv}$, sometimes going to zero for short periods. The descent to Lima showed two separated air masses. Above $7 \mathrm{~km}$ altitude, when the aircraft was inside clouds, the NO mixing ratio varied up to 150 pptv. The calculated back trajectories had their origin east of the aircraft over the continent. Below $7 \mathrm{~km}$ the NO mixing ratio was around 0 to $50 \mathrm{pptv}$ without elevated mixing ratios near the surface. Local 

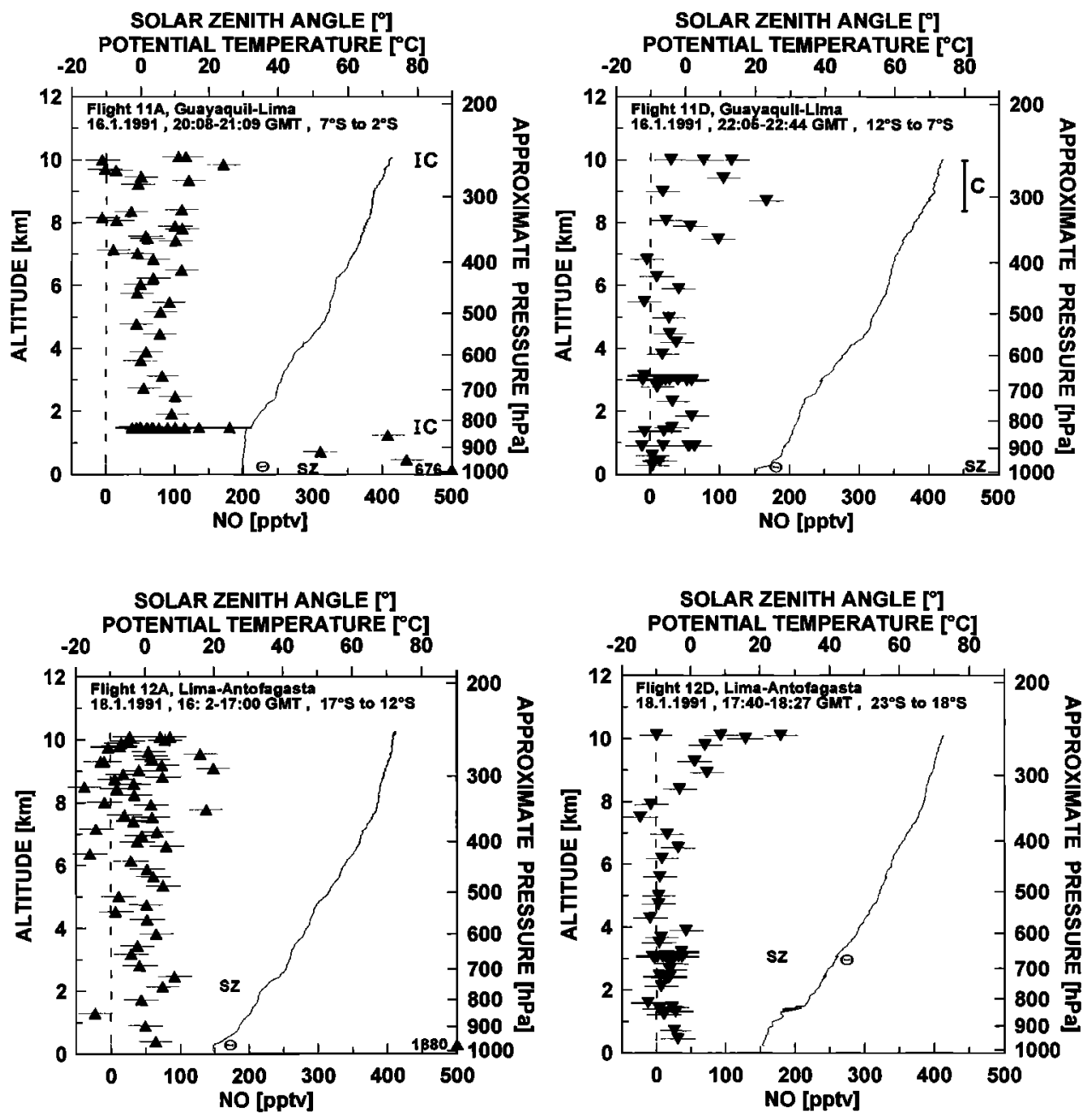

Figure 10. Vertical profiles of the NO mixing ratio (top) during flight 11, Guayaquil-Lima, and (bottom) during flight 12, Lima-Antofagasta. See Figure 5 for explanation of the symbols.

winds were light and from the south to southeast. The origin of the air masses was west of the aircraft over the near-shore ocean.

\section{Flight 12}

Two days later, on January 18,1991 , at 1602 UT, a value of 1.9 parts per billion by volume (ppbv) of NO was measured during the ascent from Lima near the airport. At higher altitudes the NO mixing ratio was around $50 \mathrm{pptv}$. Above $6 \mathrm{~km}$ the NO showed peaks up to $150 \mathrm{pptv}$. Local surface winds were from the south and veered to west-northwest by the time the aircraft reached cruising altitude. Cumulonimbus clouds were observed in the vicinity of the aircraft. At the descent to Antofagasta, 75 pptv of NO were measured down to 8 $\mathrm{km}$ altitude. Below that the NO values were around 0 to $25 \mathrm{pptv}$, with some peaks to 50 pptv. The back trajectories showed two different origins: north to northeast over the continent for the higher altitudes and south to southwest over the ocean for the lower altitudes. At the altitude of $3 \mathrm{~km}$ a brownish haze indicating local pollution could be seen outside the aircraft, but it had no influence on the NO measurement.

\section{Flight 13}

The ascent from Antofagasta showed slightly elevated NO mixing ratios around 20 to 50 pptv, but again no indication of pollution near the ground. The potential temperature indicated a strong separation of layers at $1.2 \mathrm{~km}$ altitude. The descent to Santiago showed a layer of $50 \mathrm{pptv} \mathrm{NO}$ at 5 to $7 \mathrm{~km}$ altitude with values near zero above and below that layer. This layer was accompanied by changes in the slope of potential temperature at 5.5 and $6 \mathrm{~km}$ altitude. At $2.5 \mathrm{~km}$ altitude a sharp gradient was measured with NO values between 100 and 200 pptv in the polluted layer near the surface. For the ascent from Antofagasta the back trajectories showed advection of air masses from coastal to continental regions in the north. Near Santiago, maritime air masses were advected from the west.

\section{Flight 14}

During the ascent from Santiago on January 21, 1991, at $1317 \mathrm{UT}$, the aircraft encountered an inversion layer at $1.8 \mathrm{~km}$ altitude. Below that layer, values up to 4.3 ppbv NO were measured. Just above that layer the 

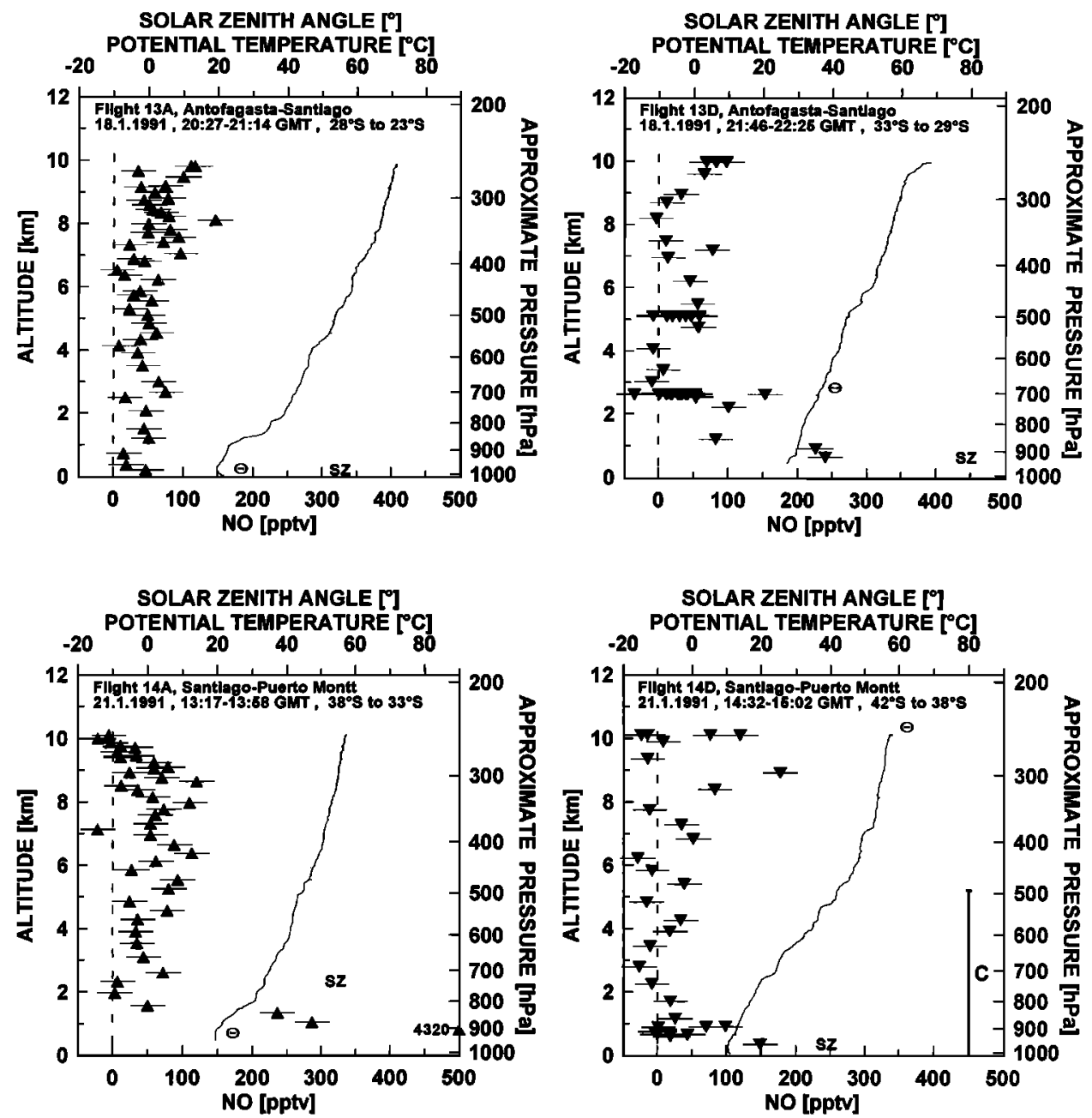

Figure 11. Vertical profiles of the NO mixing ratio (top) during flight 13, Antofagasta-Santiago, and (bottom) during flight 14, Santiago-Puerto Montt. See Figure 5 for explanation of the symbols.

NO mixing ratio was near zero. At higher altitudes the NO profile showed an increase up to $100 \mathrm{pptv}$ at $9 \mathrm{~km}$ altitude but a decrease to values near zero again at 10 $\mathrm{km}$. Local winds were from the west at all altitudes. At altitudes below $250 \mathrm{hPa}$ the back trajectories indicate the advection of air masses from the ocean at $60^{\circ}$ to $70^{\circ}$ south. At $250 \mathrm{hPa}$ the air masses were calculated to come straight from the west. During the whole descent below $5 \mathrm{~km}$ the aircraft was flying inside clouds. Local winds were from the west. Back trajectories indicated air masses from the west-southwest at all altitudes.

\section{Flight 15}

Two hours later on January 21, 1991, at $1711 \mathrm{UT}$, clouds were encountered up to $5 \mathrm{~km}$ altitude. Above $5 \mathrm{~km}$ the measured NO values strongly varied between zero and 100 pptv. Just before the descent to Punta Arenas the region of the polar jet was reached. The aircraft was flying inside the stratosphere near $11 \mathrm{~km}$ altitude. The NO mixing ratio showed values up to 250 pptv and a decrease to zero at $7 \mathrm{~km}$ altitude. Below 5 $\mathrm{km}$ the NO values varied between $-20 \mathrm{pptv}$ and 50 pptv. An additional profile flown down to $1.5 \mathrm{~km}$ altitude did not show a significant difference from the descent to Punta Arenas. When the aircraft crossed some clouds at $1.8 \mathrm{~km}$ altitude, the $\mathrm{NO}$ mixing ratio showed a peak of 80 pptv just below the clouds. The back trajectories had their origin over the Pacific west to southwest of the aircraft for the whole flight.

\section{Flight 16}

Local winds were from the west, and the air was clear. The back trajectories show the advection of air masses from the west during the whole flight. At the descent to Comodoro Rivadavia, on the east coast of South America, the air that had originated over the Pacific had moved across the narrow continent with some indication of lifting.

\section{Flight 17}

At the time of the ascent from Comodoro Rivadavia on January 22, 1991, at $1621 \mathrm{UT}$, an inversion layer 

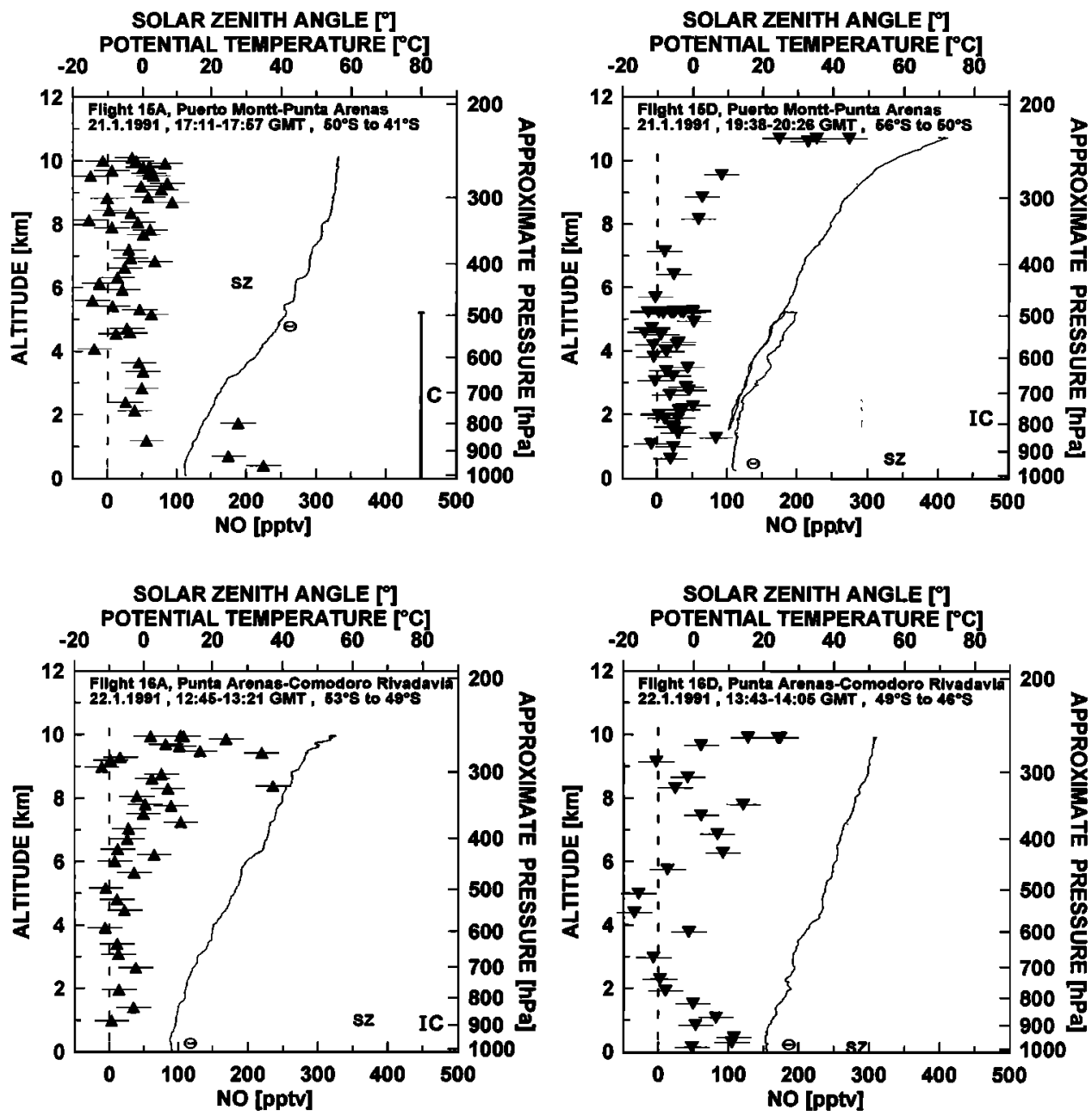

Figure 12. Vertical profiles of the NO mixing ratio (top) during flight 15, Puerto Montt-Punta Arenas, and (bottom) during flight 16, Punta Arenas-Comodoro Rivadavia. See Figure 5 for explanation of the symbols.

at $2.5 \mathrm{~km}$ altitude showed up in the profile of potential temperature but not in the NO profile. The NO values were around $100 \mathrm{pptv}$ below $1 \mathrm{~km}$, at which altitude the aircraft was flying through clouds. The NO values were around 40 to $50 \mathrm{pptv}$ for the rest of the ascent except for some lower values at $6.5 \mathrm{~km}$ altitude just above some clouds. Above $8 \mathrm{~km}$ the $\mathrm{NO}$ mixing ratio was extremely variable around $50 \pm 50$ pptv. That altitude was separated from the lower altitudes by a shallow layer of lower potential temperature. During the cruise to Buenos Aires the aircraft penetrated the stratosphere. It was still above the tropopause when it started to descend. Within the stratosphere at $\mathbf{1 0 . 5}$ $\mathrm{km}$ altitude, NO mixing ratios were around $150 \mathrm{pptv}$, going down to values near zero at $10 \mathrm{~km}$ for the rest of the descent. There were some peaks with elevated NO mixing ratios near the ground but no indication of local pollution from the city of Buenos Aires. The back trajectories originated $2000-5000 \mathrm{~km}$ west of the aircraft over the Pacific with a general tendency to descend. Near Buenos Aires at the very lowest altitudes, local winds shifted to the south, and the 3 day back trajectory remained on the continent.

\section{Flight 18}

At the start of flight 18 on January 23,1991 , at 1350 UT and different from the day before, the air masses were advected from the west at all altitudes. Consequently, during the ascent over Buenos Aires, high NO mixing ratios up to $2 \mathrm{ppbv}$ were measured in the PBL up to the inversion layer at $1 \mathrm{~km}$ altitude. At higher altitudes the NO mixing ratio decreased from $100 \mathrm{pptv}$ at $1 \mathrm{~km}$ to zero at $6 \mathrm{~km}$ altitude. In the range 6 to $10 \mathrm{~km}$, higher values with high fluctuations were measured in the range 0 to $150 \mathrm{pptv}$ NO. The 3 day back trajectories for $700 \mathrm{hPa}$ to $350 \mathrm{hPa}$ indicate the advection of maritime air from the Pacific across the continent. For 250 $\mathrm{hPa}$ the 3 day back trajectories ended over the region around Lima. Similar back trajectories were calculated for the descent to Porto Alegre. For $350 \mathrm{hPa}$ down to $700 \mathrm{hPa}$, westerly wind was advecting air masses from the Pacific across the continent. Low mixing ratios of 

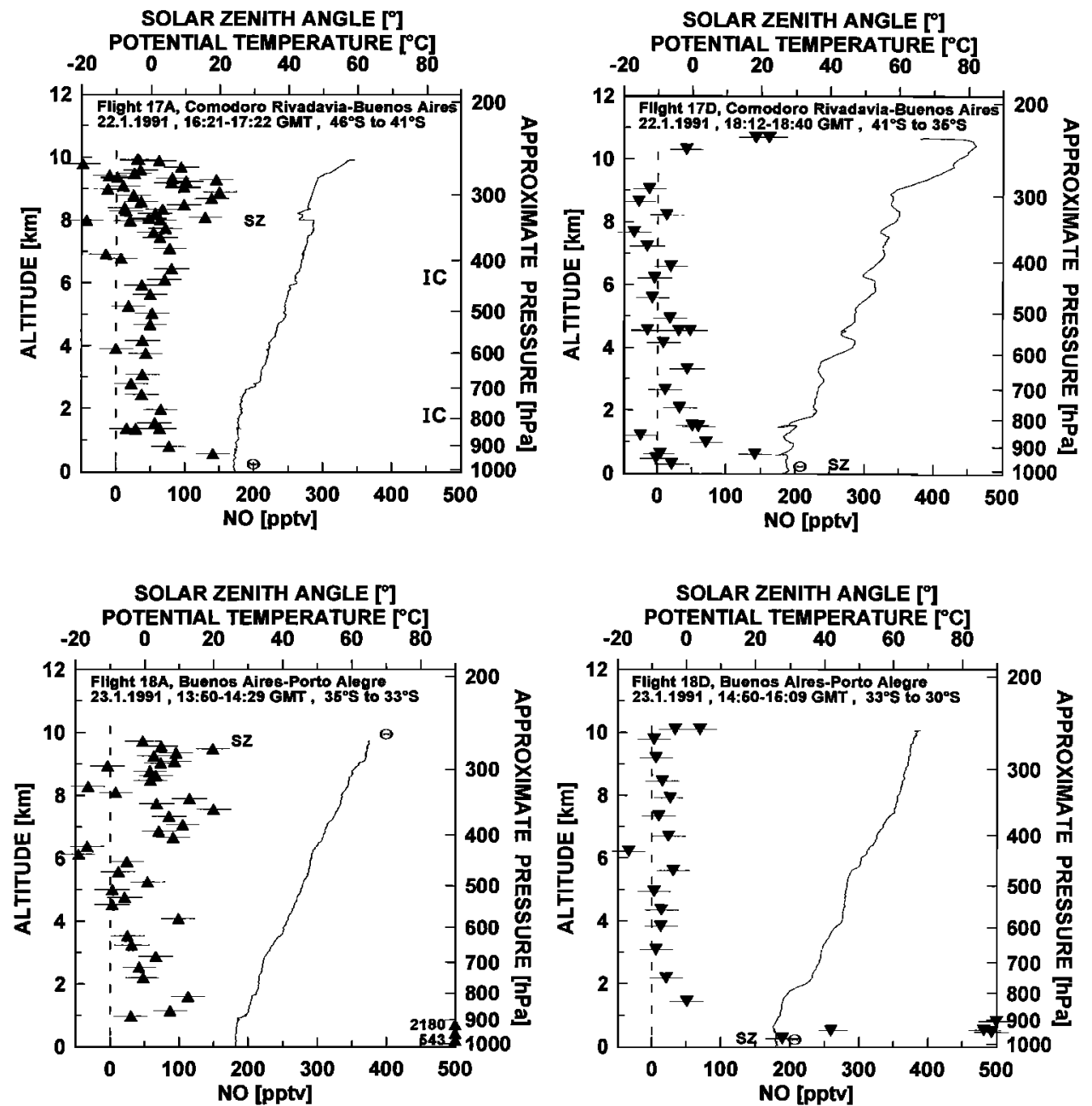

Figure 13. Vertical profiles of the NO mixing ratio (top) during flight 17, Comodoro RivadaviaBuenos Aires, and (bottom) during flight 18, Buenos Aires-Porto Alegre. See Figure 5 for explanation of the symbols.

NO in the range 0 to 20 pptv were measured. At lower altitudes the wind direction was changing to southerly. At $850 \mathrm{hPa}$ the back trajectory has its origin near Punta Arenas, then led over Buenos Aires to Porto Alegre with a descending tendency. For $950 \mathrm{hPa}$ the back trajectory indicates transport of air over the Atlantic parallel to the coastline. The NO measurement seems to reflect this transport pattern by a sharp peak of 500 pptv NO at $1 \mathrm{~km}$ altitude with lower values of $200 \mathrm{pptv}$ near the surface at the airport of Porto Alegre.

\section{Flight 19}

The ascent at Porto Alegre 2 hours later on January 23,1991 , at $1713 \mathrm{UT}$, did not show this layer of high NO mixing ratios at $1 \mathrm{~km}$ altitude, although the back trajectories remain essentially the same. In the PBL, values around $150 \mathrm{pptv}$ of NO were measured with a sharp gradient at the inversion layer at $2 \mathrm{~km}$ altitude. During the rest of the ascent, values around $50 \mathrm{pptv}$ of NO were measured. At the descent to Rio de Janeiro the aircraft was inside clouds at $4.5 \mathrm{~km}$ altitude and for the altitude range $2-0.5 \mathrm{~km}$. Inside the PBL a sharp increase to values of a few hundred parts per trillion by volume of $\mathrm{NO}$ was measured, reaching $1.2 \mathrm{ppbv} \mathrm{NO}$ near the airport.

\section{Flight 20}

The ascent from Rio on January 25, 1991, at 1310 UT, took place under completely different conditions. The back trajectories at all altitudes have an ascending component. Up to $700 \mathrm{hPa}$ the trajectories were parallel to the coastline, originating south-southwest of Rio. For the rest of the ascent they were slowly changing to westerly directions. For example, the trajectories for $350 \mathrm{hPa}$ altitude originated at $820 \mathrm{hPa}$ west of Rio in the center of the South American continent $\left(20^{\circ} \mathrm{S}, 60^{\circ} \mathrm{W}\right)$. In this altitude range from 8.5 to $10 \mathrm{~km}$, the aircraft was inside clouds. This altitude region is sharply separated in the vertical profile of NO with values around 350 pptv of NO. At lower altitudes, values around 100 pptv NO were found. For the descent to Salvador the back trajectories below $350 \mathrm{hPa}$ were changing to east- 

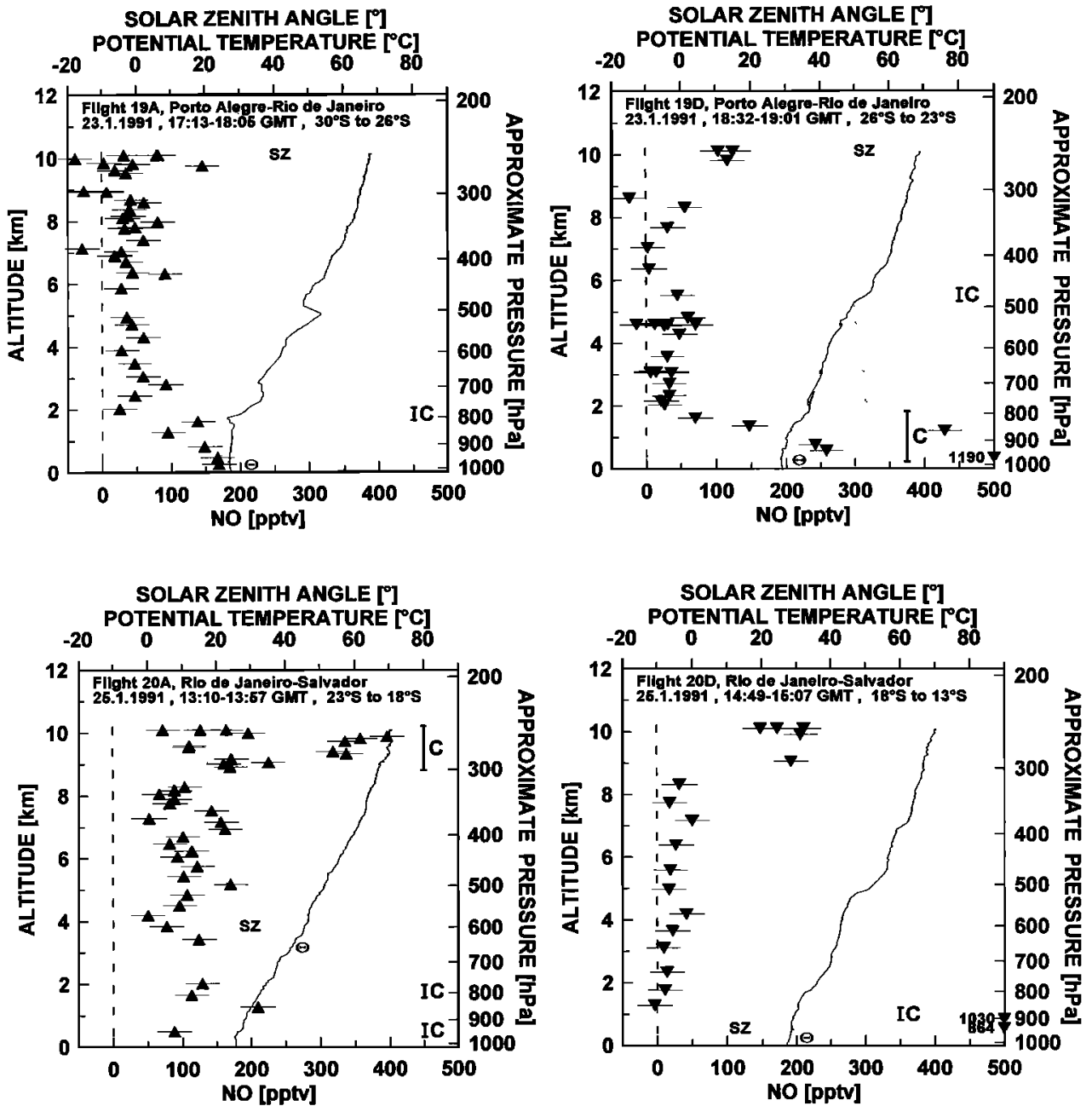

Figure 14. Vertical profiles of the NO mixing ratio (top) during flight 19, Porto Alegre-Rio de Janeiro, and (bottom) during flight 20, Rio de Janeiro-Salvador. See Figure 5 for explanation of the symbols.

erly without an indication for vertical transport and indicate advection of air from the Atlantic. They indicate the sampling of maritime air. Above $350 \mathrm{hPa}$, NO values of up to $200 \mathrm{pptv}$ were found. Below, the NO values decreased sharply to $0-25 \mathrm{pptv}$. The PBL seemed to be located at $1.9 \mathrm{~km}$ altitude, but NO values increased sharply to $1 \mathrm{ppbv}$ only below the clouds at 1 $\mathrm{km}$ altitude.

\section{Flight 21}

During the ascent from Salvador on January 25, 1991, at $1634 \mathrm{UT}, 2$ hours later, we experienced problems with the flowcontrollers. Thus the data between 1 and $2 \mathrm{~km}$ altitude were discarded. The back trajectories during this ascent were very similar to those for the descent to Salvador except above $350 \mathrm{hPa}$, where the uplifting motion had ceased. The descent to Fortaleza encountered clouds below $1 \mathrm{~km}$ altitude. The back trajectory for 350 $\mathrm{hPa}$ followed the coastline southwest of Fortaleza. The trajectories for lower altitudes indicate the transport of Atlantic air masses from the east.

\section{Flight 22}

Flight 22, Fortaleza-Recife, took place during zenith angles higher than $85^{\circ}$. The measured NO values were around zero at all altitudes for the dark period at descent. Some higher values were found during the ascent when the zenith angles were still below $90^{\circ}$.

\section{Flights 25 to 27}

For the transfer flights from Recife to Abidjan, most of the scientists had to leave the research aircraft and to cross the ocean by commercial flights. Thus no measurements of $\mathrm{NO}$ are available for flights 23 and 24 . Additionally, during flight 27, from Abidjan to Dakar, a major breakdown of the power supply of the experiment prevented the NO measurement for the descent to Dakar and for flight 28, Dakar to Las Palmas.

The meteorological conditions were very similar for all of the flights $(25,26$, and 27$)$ in the region near Abidjan. For the ascent from and the descent to Abidjan near the coast the back trajectories showed the ad- 

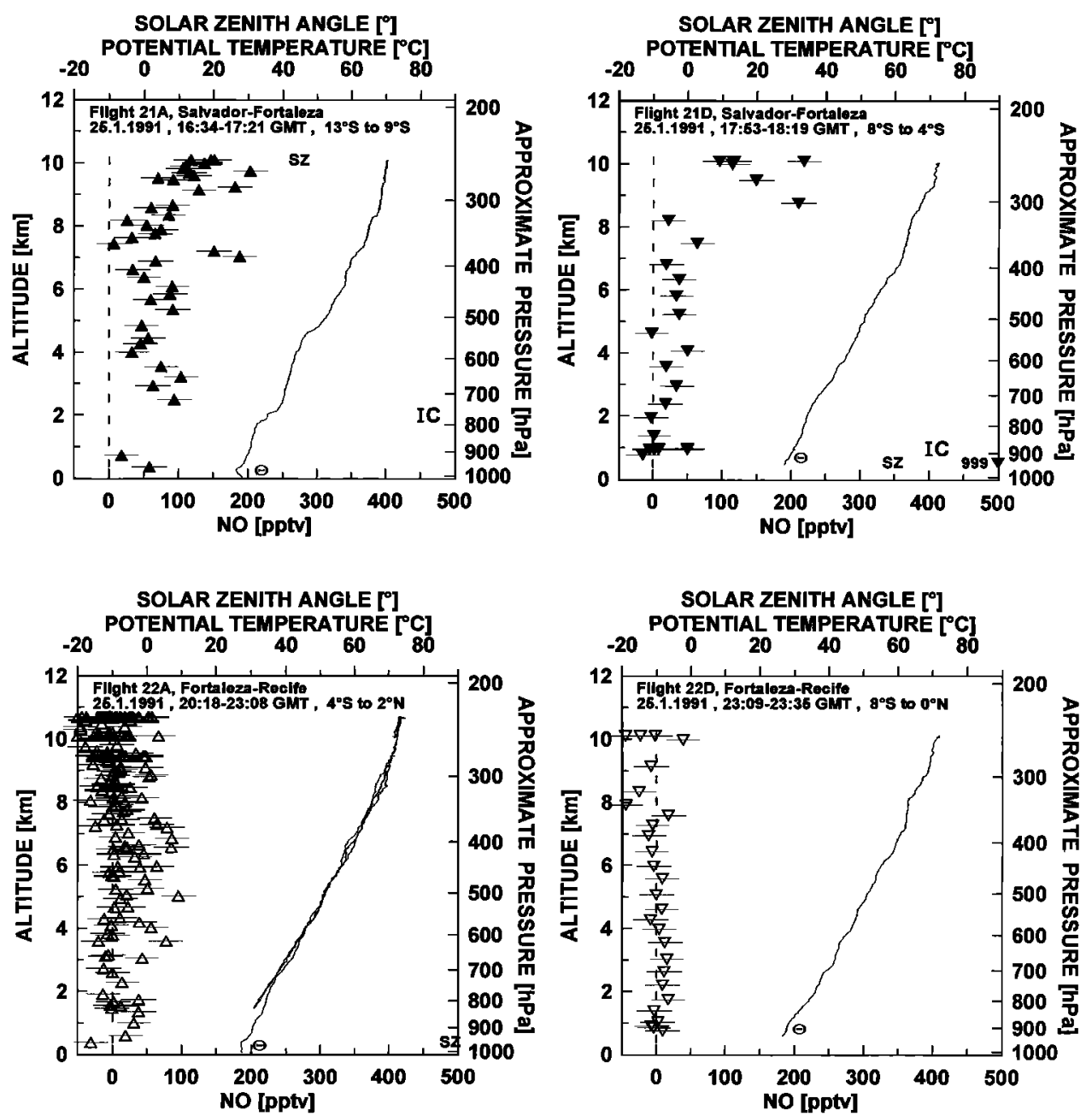

Figure 15. Vertical profiles of the NO mixing ratio (top) during flight 21, Salvador-Fortaleza, and (bottom) during flight 22, Fortaleza-Recife. See Figure 5 for explanation of the symbols.

vection of maritime air from the south up to altitudes of $1 \mathrm{~km}$. Between 1 and $3 \mathrm{~km}$, air masses with continental origin east of Abidjan were encountered. Above $3 \mathrm{~km}$ the trajectories changed back again to southern directions.

The profiles of potential temperature indicated stable conditions for the lower altitudes near the coast. Here the profiles showed relatively low NO mixing ratios of about 50 pptv.

Additionally, a number of profiles during these flights were taken farther inland down to altitudes of $500 \mathrm{~m}$. The profiles of potential temperature indicated unstable conditions there. This finding suggested good vertical mixing in the layer up to $3 \mathrm{~km}$ altitude above the continent. In this layer the video system also recorded the appearance of a yellowish haze, sharply separated from the air layer above. The NO measurements reflected these observations. The NO mixing ratio at the lower altitudes was significantly higher over the continent than near the coastline. Between 1 and $3 \mathrm{~km}$ the NO values generally increased linearly with altitude up to $400 \mathrm{pptv}$ NO. This increase of NO with altitude was accompanied by a linear increase of the photolysis frequency of $\mathrm{NO}_{2}$ inside the layer, whereas ozone concentrations remained approximately constant. These observations indicate an almost constant mixing ratio of $\mathrm{NO}_{x}$ between 1 and $3 \mathrm{~km}$ over the continent. However, above $3 \mathrm{~km}$ altitude, when the aircraft was leaving the layer with the yellowish haze, the NO data showed a very sharp decrease down to values around 50 pptv NO. During flight 26, during which the aircraft reached $9 \mathrm{~km}$ altitude, there was a shallow layer of elevated NO mixing ratio up to $150 \mathrm{pptv}$ at $7 \mathrm{~km}$ altitude. Above that level the NO mixing ratio was around 50 pptv again. Although no active brushfire could be seen during the flights near Abidjan, the whole region up to altitudes of $3 \mathrm{~km}$ seemed to be affected by upwind brushfires.

\section{Flight 29}

At the ascent from Las Palmas on February 1, 1991, at $1027 \mathrm{UT}$, a very strong inversion layer was encountered up to altitudes of $500 \mathrm{~m}$ with low NO mixing ratios. The back trajectories indicated the advection of maritime air from northwesterly directions. The air- 

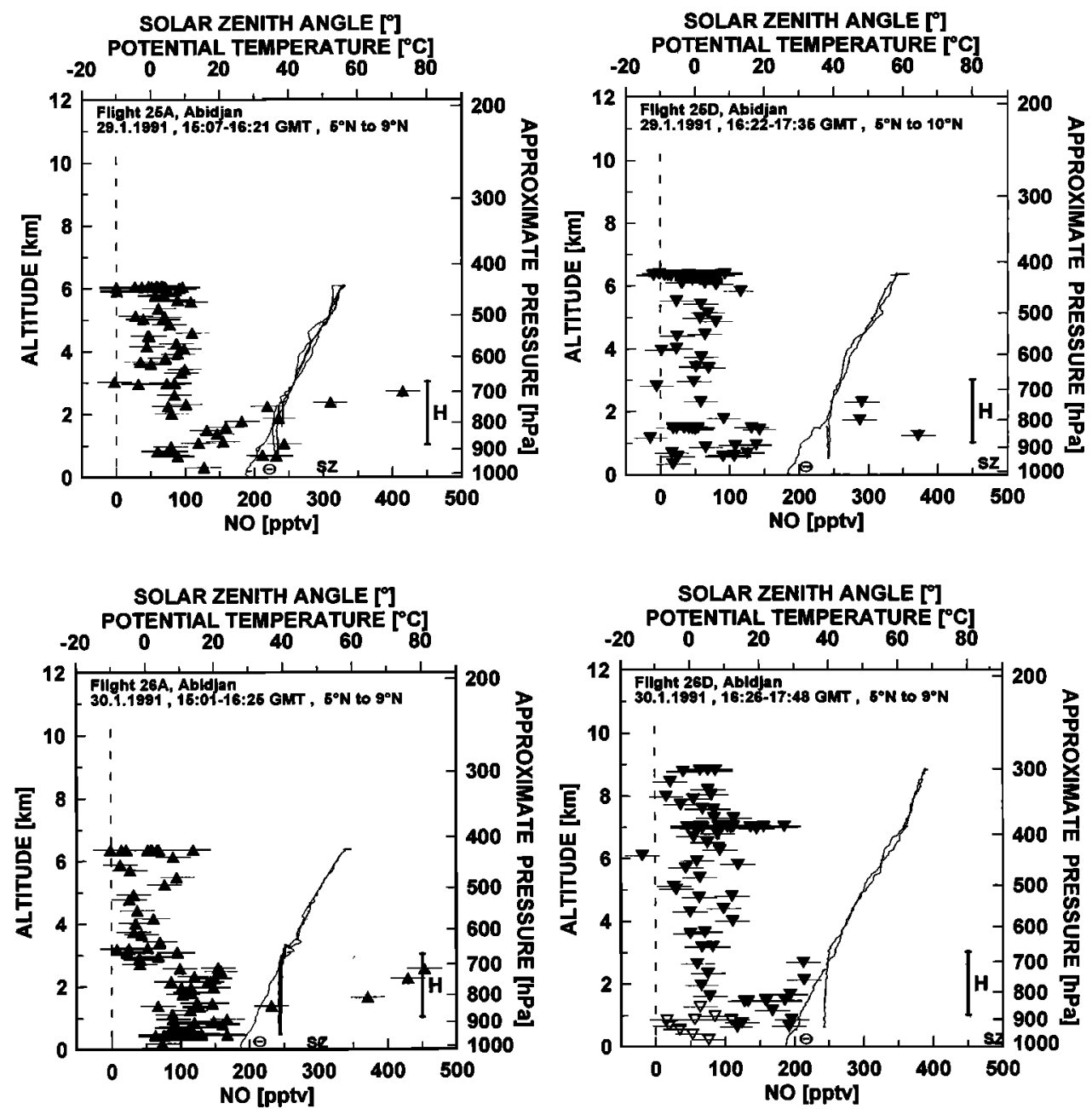

Figure 16. Vertical profiles of the NO mixing ratio during local flights (top) 25 and (bottom) 26 near Abidjan. See Figure 5 for explanation of the symbols.

craft crossed through some clouds at $500 \mathrm{~m}$ altitude accompanied by a slight increase of the NO mixing ratio up to $50 \mathrm{pptv}$. The back trajectories indicated the advection of air masses leaving the North American continent 3 days before the flight. During the descent to Lisbon an inversion layer was encountered at $1.8 \mathrm{~km}$ altitude, indicated by the gradient of the potential temperature and the presence of clouds. The NO mixing ratio showed a very steep gradient from $0-50$ pptv above $1.8 \mathrm{~km}$ altitude up to $450 \mathrm{pptv}$ at $1.8 \mathrm{~km}$ with high fluctuations below, following the variations of the photolysis frequency of $\mathrm{NO}_{2}$.

\section{Flight 30}

Two hours later, when the aircraft began its ascent at Lisbon on February 1, 1991, at 1429 UT, the inversion layer was still located at the same altitude. In contrast to the previous descent, however, no enhanced NO mixing ratios were detected in the PBL. The NO values were in the region of $40 \mathrm{pptv}$ for the whole ascent up to altitudes of $8 \mathrm{~km}$ when the aircraft penetrated the tropopause. Near Brétigny the solar zenith angle was greater than $85^{\circ}$. So, during the descent, low NO values around zero were measured. When the aircraft entered the PBL at $1 \mathrm{~km}$ altitude, the solar zenith angle was near $90^{\circ}$. Nevertheless, the NO mixing ratios increased to $100-200 \mathrm{pptv}$, indicating high local pollution.

\section{Discussion}

Most of the vertical NO profiles show a fair amount of scatter. Some of that is instrumental. Especially at low NO levels the relatively large measurement error of \pm 25 pptv introduces a fair amount of noise. Another source of variability comes from the fact that atmospheric NO is not a conserved quantity. It interconverts within minutes with $\mathrm{NO}_{2}$, the partitioning between the two depending on the local flux of solar photons (via $\mathrm{J}\left(\mathrm{NO}_{2}\right)$ ) and the local ozone concentration. Since both of these parameters vary in space and time, they contribute to the scatter in the NO data on all timescales. Larger excursions are often in the form of 

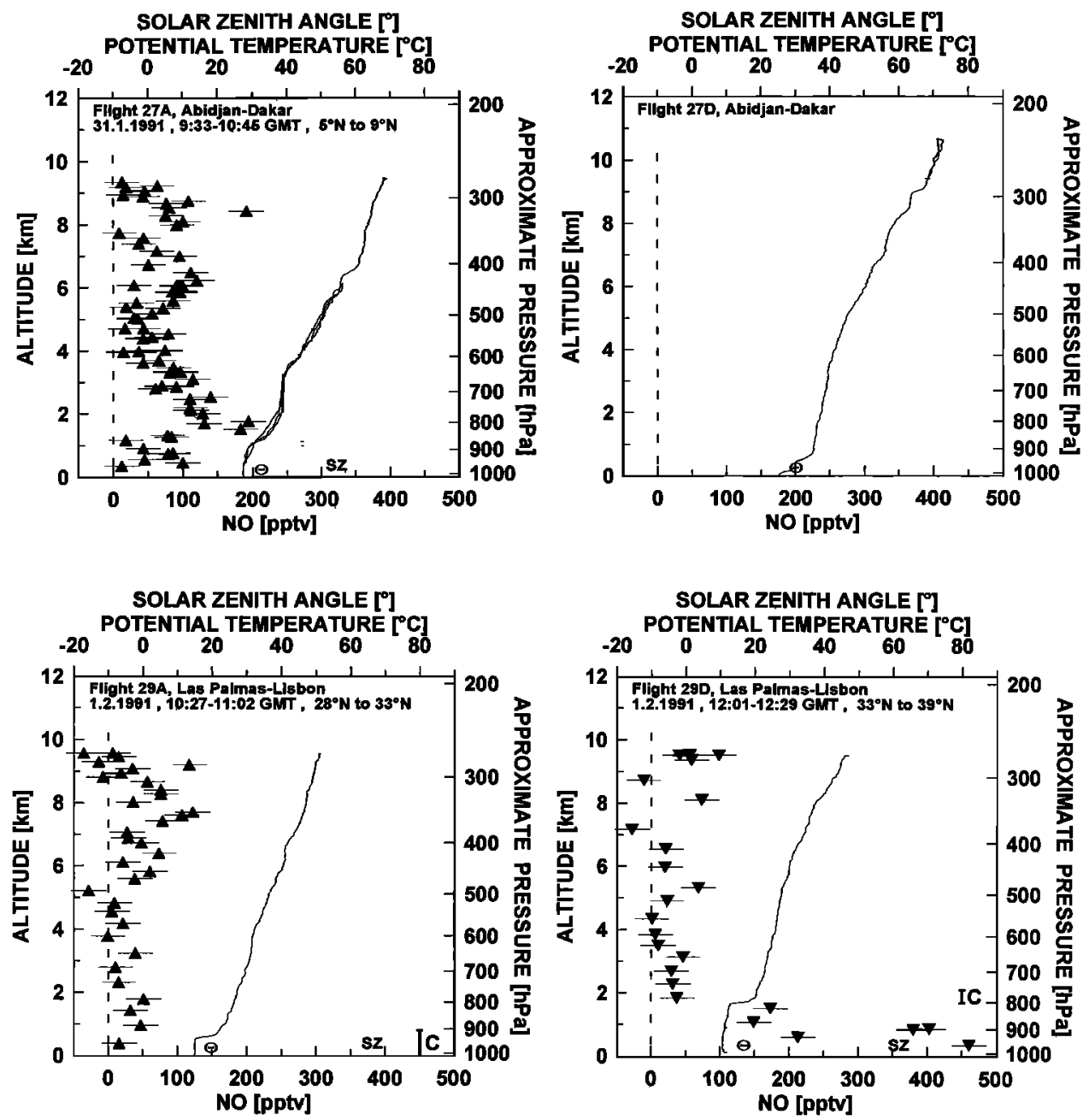

Figure 17. Vertical profiles of the NO mixing ratio (top) during flight 27, Abidjan-Dakar, and (bottom) during flight 29, Las Palmas-Lisbon. See Figure 5 for explanation of the symbols.

spikes, including one or two data points (25-100 s duration). These spikes are observed at all altitudes. They indicate the presence of layers of enhanced NO concentrations on scales smaller than several hundred meters vertically and a few kilometers horizontally. However, the scatter is not as large as one might have expected for a compound like $\mathrm{NO}$ as a member of the $\mathrm{NO}_{x}$ family with lifetimes between $1 / 2$ day in the sunlit planetary boundary layer to a week in the upper troposphere.

Over and above the scatter the vertical profiles do exhibit some systematic features as well, which point to some large-scale coherence in the data and thus to structure in the atmospheric processes that determine the tropospheric distribution of NO. Much of that coherence has to do with the fact that the wind field at nearly all different locations during the TROPOZ II campaign was reasonably close to the climatological average, i.e., strong westerly winds at all altitudes in the northern and southern midlatitudes, with weak and more variable winds in the tropics. Since the flight route led along the continental shoreline (see Figure 1), the observed air masses were coming from the North Ameri- can continent for all of flights 4 to 7 and from the South American continent for flights 16 to 22 . For the flights along the western coast of the continents the air masses were coming off the ocean: from the Pacific for flights 10 to 15 along the South American west coast and from the Atlantic for flights 1 to 3 and 24 to 30 along the African and European west coasts. Since most of the NO emissions are located over the continents [see Ehhalt et al., 1992], the flights off the east coast of North America (flights 4 to 7) and South America (flights 16 to 22) experienced air with significantly higher NO concentrations than the flights along the west coasts of South America (flights 10 to 15) and Africa/Europe (flights 1 to 3 and 24 to 30 ).

In addition, the profiles in the northern hemisphere showed little vertical gradient regardless of whether the air came from the continent or the ocean. In contrast, the air coming off the South American continent showed a considerable vertical gradient with elevated concentrations at high altitudes, which resulted in C-shaped profiles whenever surface NO concentrations were high.

To bring out the large-scale structure more clearly 

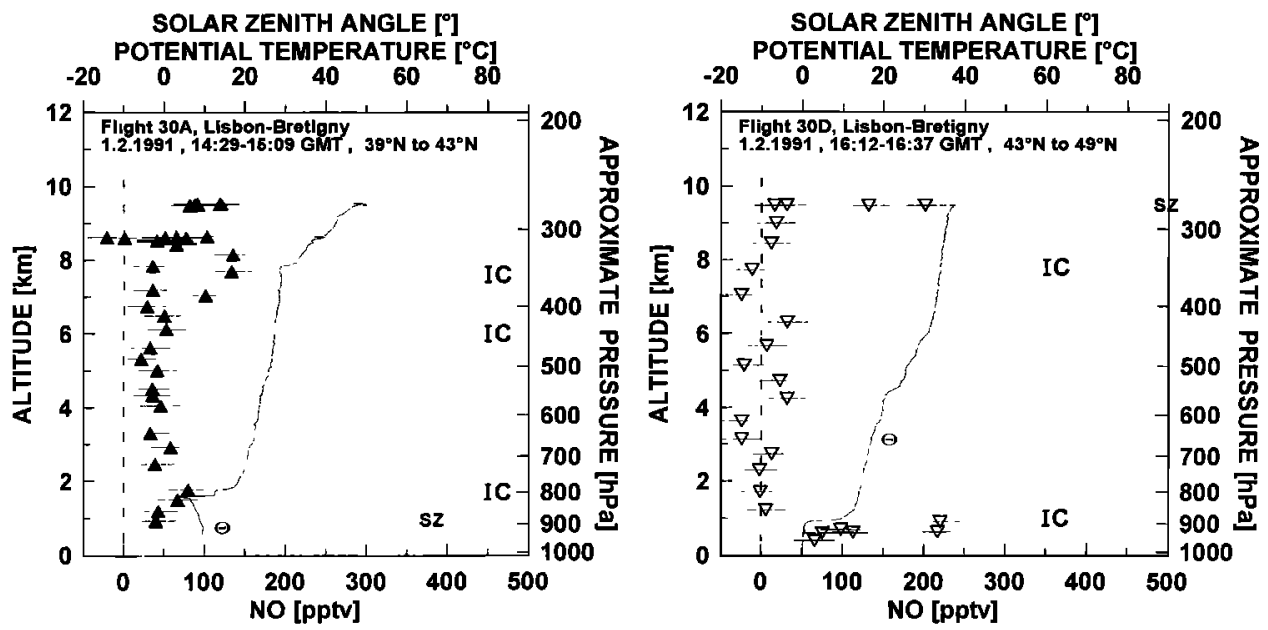

Figure 18. Vertical profiles of the NO mixing ratio during flight 30, Lisbon-Brétigny. See Figure 5 for explanation of the symbols.

and also to utilize the data collected at cruising altitude to some extent, the NO measurements are summarized in the form of latitude by altitude cross sections (Figures 19 and 20). This presentation includes several steps of averaging and filtering:

1. To remain reasonably comparable, only the NO data measured at solar zenith angles less than $80^{\circ}$ are used. Measurements below $1 \mathrm{~km}$ altitude (and below $3 \mathrm{~km}$ altitude near Cali) were also excluded to prevent contamination of the cross sections by data from locally polluted environments near airports or large cities. With the stated exclusions, all NO data, including those (positive and negative) below the detection limit, were used.

2. These data are then averaged into a grid of $1 \mathrm{~km}$ altitude by $10^{\circ}$ latitude boxes.

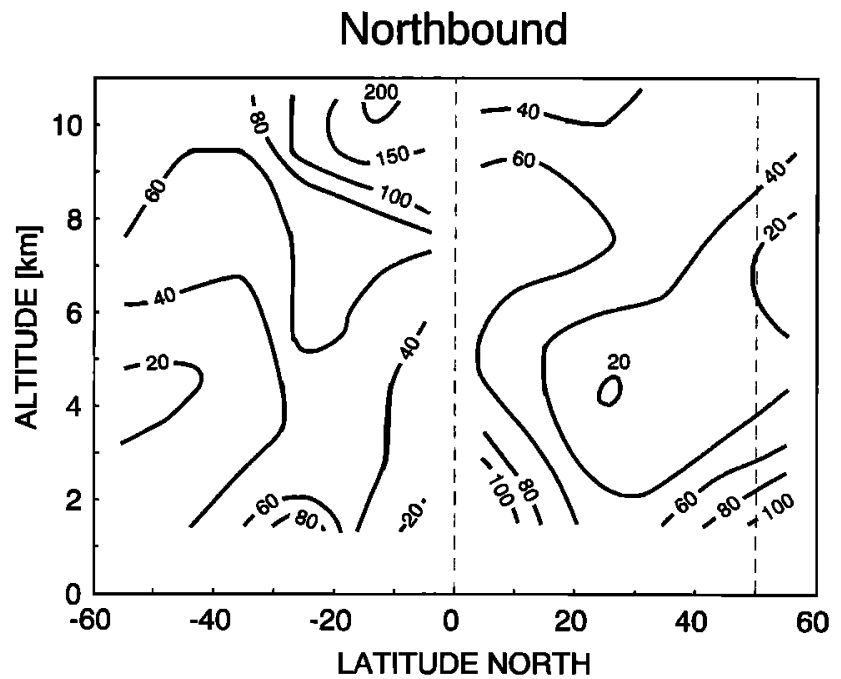

Figure 19. Averaged latitude-altitude cross sections of the NO mixing ratio during TROPOZ II for the northbound flights. The contours of constant mixing ratio are given at $20,40,60,80,100,150$, and 200 pptv. The vertical dashed lines separate the different regions used in the averaging procedure (see text).
3. Because of the different wind conditions this step is done separately for the southbound flights (flights 4 to 15) from Sondrestrom, $67^{\circ} \mathrm{N}$, to Punta Arenas, $53^{\circ} \mathrm{S}$ latitude, and for the northbound flights (flights 24 to 30) from Punta Arenas to Brétigny, $48^{\circ} \mathrm{N}$ latitude. The northbound flights include also the early section of the campaign from Brétigny to Sondrestrom (flights 1 to 3 ), although they are separated by a time period of 3 weeks.

4. The data were further averaged over adjacent boxes to remove excursions and to fill in eventual gaps. This procedure was done by assigning a weight of 0.5 to each center box and 0.5 to the mean of all neighboring boxes. To account for the different flight sections with onshore and offshore winds, the latter procedure was applied separately to the $60^{\circ} \mathrm{N}$ to $0^{\circ}$ and $0^{\circ}$ to $60^{\circ} \mathrm{S}$ sec-

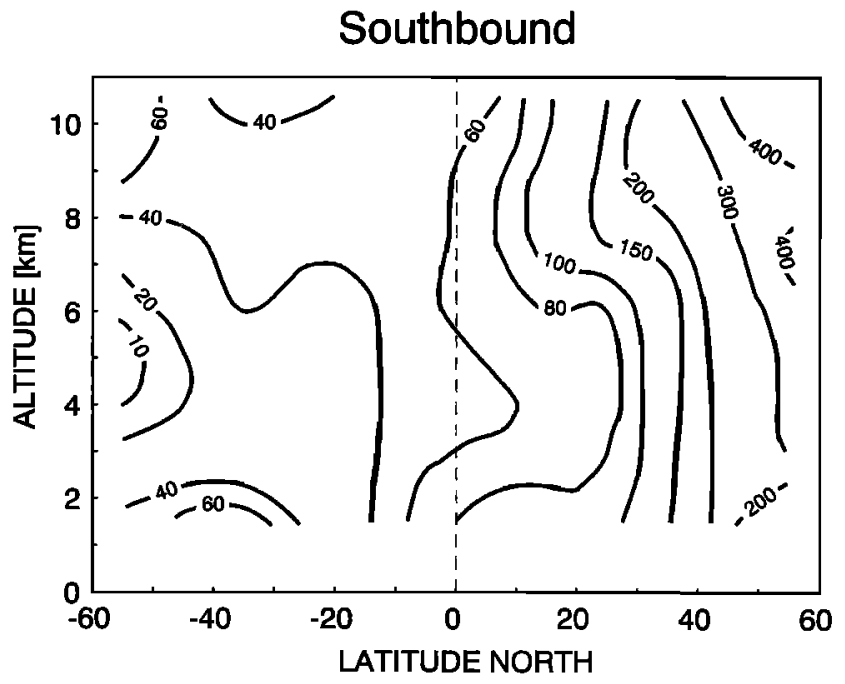

Figure 20. Averaged latitude-altitude cross sections of the NO mixing ratio during TROPOZ II for the southbound flights. The contours of constant mixing ratio are given at $10,20,40,60,80,100,150,200,300$, and 400 pptv. The vertical dashed line separates the different regions used in the averaging procedure (see text). 
tions of the southbound and northbound flights. Moreover, because of the large time gap between the early and main part of the northbound flights, the early parts (i.e., latitudes north of $50^{\circ} \mathrm{N}$ ) were treated separately as well.

The contours of constant mixing ratios drawn through the averaged NO mixing ratios are displayed in Figures 19 and 20. These plots are the projection of the average NO mixing ratios measured along the flight track onto the meridional plane. Because the flight track is oriented essentially north-south (see Figure 1), this projection leads to little distortion at most latitudes, except for the most northern latitudes, where the flight track is virtually east-west. Note that Figures 19 and 20 are primarely a convenient way to display the NO data in a coherent fashion and should not be construed as a representation of the mean zonal distribution of NO. However, the wind patterns during the campaign were close to the climatological mean. For this reason we think that Figures 19 and 20 do reflect the typical NO distribution for the regions covered by the flight track and the month of sampling.

The contours in Figures 19 and 20 emphasize and extend the features already noted in the vertical NO profiles. But the contours are relatively smooth, although the individual profiles are often disturbed by local events, for example, in the vicinity of clouds.

Figure 20 features a strong, monotonic latitudinal gradient, which dominates the NO distribution during the southbound flights. It is a result of westerly airflow blowing polluted air from the North American continent across the flight track at most of the northern latitudes, but clean Pacific air across the flight track along the South American west coast, thus greatly exaggerating any real interhemispheric gradient. This effect is seen in considering the NO distribution measured during the northbound flights (Figure 19). In this case the situation is reversed: at southern latitudes, polluted air is coming off the South American continent, and clean air is coming from the Atlantic, at least north of $20^{\circ} \mathrm{N}$ latitude. In this case there is hardly any systematic interhemispheric gradient. Taken together, both cross sections provide an indication of how much NO is picked up by the air masses as they traverse the South American continent. Clearly, the amount of NO added becomes larger for trajectories close to the equator as the continent becomes wider. Since most of the nitrogen oxides are emitted from continental surface sources (biomass burning, soil emissions, or anthropogenic emissions), a wider continent should increase the probability of picking up surface emissions. Similarly, the data in the northern hemisphere indicate a loss of NO as the air crosses the Atlantic. Because of the time differences involved in the sampling and differences in transport regimes, in both cases, simulation by a three-dimensional chemical tracer model is required for a quantitative analysis.
The two-dimensional NO distribution during the southbound flight also confirms the lack of a vertical gradient except for the latitudes south of $40^{\circ} \mathrm{S}$. In contrast, the air coming off the summertime South American continent shows a reasonably strong vertical gradient with large enhancement of the NO mixing ratio in the upper troposphere. The largest enhancements at $11 \mathrm{~km}$ altitude and $20^{\circ} \mathrm{S}$ to $0^{\circ}$ latitude were obtained during flights 20 and 21 near Rio de Janeiro, Salvador, and Fortaleza. In those cases, some of the back trajectories indicate uplift of surface air from the center of the continent.

It is interesting to briefly compare the latitude by altitude cross sections observed during TROPOZ II with those obtained during STRATOZ III [Drummond et al., 1988; Ehhalt and Drummond, 1988; Ehhalt et al., 1992]. The latter campaign had essentially the same flight track but took place in the northern summer, i.e., June 1984. The data from the STRATOZ III campaign showed strong enhancements of the NO mixing ratio in the upper troposphere over the summertime continents in the northern hemisphere and, to a lesser extent, also over the tropical continents of the southern hemisphere, quite symmetric to the situation found here in TROPOZ II. The authors quoted invoked fast vertical transport of polluted surface air, NO produced in lightning, and emissions by high-flying aircraft as the chief sources of enhanced NO over the American and European continent found during STRATOZ III. It appears that at least the first two of these sources are also indicated for the enhanced NO concentrations found leeward of the South American continent during TROPOZ II.

Although they are suggestive, the observed distributions of NO can provide only a preliminary mapping of the distribution of $\mathrm{NO}_{x}$. $\mathrm{NO}_{x}$ is a much better conserved quantity and therefore is much better suited to study the chemical and meteorological processes that determine the tropospheric $\mathrm{NO}_{x}$ and thus NO distribution.

From the average distribution of $\mathrm{O}_{3}$ and the calculated photolysis frequency of $\mathrm{NO}_{2}, \mathrm{~J}\left(\mathrm{NO}_{2}\right)$, one obtains a mean NO to $\mathrm{NO}_{x}$ ratio of 0.3 at $1 \mathrm{~km}$ altitude, which increases nearly linearly to 0.8 at $10 \mathrm{~km}$. For a rough estimate of the $\mathrm{NO}_{x}$ distribution we can superimpose these factors on the measured NO distributions. This process will enhance the $\mathrm{NO}_{x}$ concentrations in the upper troposphere only weakly with respect to the NO mixing ratios and those in the lower troposphere by a factor of 3 . As a consequence the vertical $\mathrm{NO}_{x}$ distribution derived from Figures 19 and 20 would show a decrease in concentration with altitude everywhere except for the northbound flights in the southern hemisphere, which would become more strongly $\mathrm{C}$ shaped. Thus it will not affect the qualitative conclusions drawn so far. A proper calculation of the $\mathrm{NO}_{x}$ fields and a more quantitative analysis will become possible once the fi- 
nal $\mathrm{O}_{3}$ mixing ratios (A. Marenco, unpublished manuscript, 1996) and $\mathrm{J}\left(\mathrm{NO}_{2}\right)$, which were also measured during TROPOZ II, become available.

\section{Conclusion}

The data measured during TROPOZ II present a large-scale overview of the NO concentration in the troposphere along the continental margin of eastern North America, South America, western North Africa, and Europe. Since they were taken during the northern hemispheric winter, they are complementary to the data of STRATOZ III, which were taken along the same flight track in summer. Both data sets show the large influence of continental $\mathrm{NO}_{x}$ sources, and maritime air exhibits low $\mathrm{NO}_{x}$ concentrations. Both data sets indicate the importance of fast upward transport of polluted air to the $\mathrm{NO}_{x}$ mixing ratios in the upper troposphere over the summer continents.

Acknowledgments. The authors would like to thank Alain Marenco and the crew of the Caravelle at the Centre d'Essais en Vol at Brétigny sur l'Orge for organizing the flights and assistance before and during the expedition. The help by $M$. Weber, A. Khedim, and M. Plum in the preflight preparation of the equipment is gratefully acknowledged. This work was financially supported by the Bundesminister für Forschung und Technologie of the Federal Republic of Germany.

\section{References}

Arlander, D. W., D. Brüning, U. Schmidt, and D. H. Ehhalt, The distribution of acetaldehyde in the lower troposphere during TROPOZ II, J. Atmos. Chem., 22, 243-249, 1995 a.

Arlander, D. W., D. Brüning, U. Schmidt, and D. H. Ehhalt, The tropospheric distribution of formaldehyde during TROPOZ II, J. Atmos. Chem., 22, 251-268, 1995 b.

Drummond, J. W., A. Volz, and D. H. Ehhalt, An optimized chemiluminescence detector for tropospheric NO measurements, J. Atmos. Chem., 2, 287-306, 1985.

Drummond, J. W., D. H. Ehhalt, and A. Volz, Measurements of nitric oxide between $0-12 \mathrm{~km}$ altitude and $67^{\circ} \mathrm{N}$ to $60^{\circ} \mathrm{S}$ latitude obtained during STRATOZ III, J. Geophys. Res., 93, 15,831-15,849, 1988.

Ehhalt, D. H., and J. W. Drummond, $\mathrm{NO}_{x}$ sources and the tropospheric distribution of $\mathrm{NO}_{x}$ during STRATOZ III, in Tropospheric Ozone, edited by I. S. A. Isaksen, 217-237, D. Reidel, Norwell, Mass., 1988.

Ehhalt, D. H., F. Rohrer, and A. Wahner, Sources and distribution of $\mathrm{NO}_{\mathrm{x}}$ in the upper troposphere at northern mid-latitudes, J. Geophys. Res., 97, 3725-3738, 1992.

Gouget, H., J.-P. Cammas, A. Marenco, R. Rosset, and I. Jonquières, Ozone peaks associated with a subtropical tropopause fold and with the trade wind inversion: A case study from the airborne campaign TROPOZ II over the Caribbean in winter, $J$. Geophys. Res., 101, 25,979$25,993,1996$.

Junkermann, W., U. Platt, and A. Volz-Thomas, A photoelectric detector for the measurement of photolysis frequencies of ozone and other atmospheric molecules, $J$. Atmos. Chem., 8, 203-227, 1989.

Kley, D., and M. McFarland, Chemiluminescence detector for $\mathrm{NO}$ and $\mathrm{NO}_{2}$, Atmos. Technol., 12, 62-69, 1980.

Perros, P. E., Large-scale distribution of peroxyacetylnitrate from aircraft measurements during the TROPOZ II experiment, J. Geophys. Res., 99, 8269-8279, 1994.

Ridley, B. A., and L. C. Howlett, An instrument for NO measurements in the stratosphere, Rev. Sci. Instrum., 45, 742-746, 1974.

Rohrer, F., and D. Brüning, Surface $\mathrm{NO}$ and $\mathrm{NO}_{2}$ mixing ratios measured between $30^{\circ} \mathrm{N}$ and $30^{\circ} \mathrm{S}$ in the Atlantic region, J. Atmos. Chem., 15, 253-267, 1992.

Roths, J., Entwicklung eines flugtauglichen laserspektroskopischen Spurengassensors und dessen Einsatz bei der TROPOZ II Flugmeßkampagne, Ph.D. thesis, Univ. Mainz, Mainz, Germany, 1992.

Roths, J., and G. W. Harris, The tropospheric distribution of carbon monoxide as observed during the TROPOZ II experiment, J. Atmos. Chem., 24, 157-188, 1996.

Wolz, G., Meridionale Vertikalverteilung des atmosphärischen Schwefeldioxids in der Troposphäre, technical report, Univ. Frankfurt/Main, Frankfurt/Main, Germany, 1992.

D. Brüning, D.H. Ehhalt, and F. Rohrer, Institut für Atmosphärische Chemie, Forschungszentrum Jülich, D-52425 Jülich, Germany. (e-mail:f.rohrer@fz-juelich.de)

(Received May 9, 1995; revised March 26, 1997; accepted June 19, 1997.) 